\title{
The cannabinoid ligands SR141716A and AM251 enhance human and mouse islet function via GPR55-independent signalling
}

\author{
Inmaculada Ruz-Maldonado ${ }^{1}$ (C) B Bo Liu ${ }^{1} \cdot$ Patricio Atanes $^{1} \cdot$ Attilio Pingitore $^{1} \cdot$ Guo Cai Huang ${ }^{1} \cdot$ Pratik Choudhary $^{1}$. \\ Shanta J. Persaud ${ }^{1}$ [D
}

Received: 15 August 2019 / Revised: 2 December 2019 / Accepted: 18 December 2019 / Published online: 10 January 2020

(c) The Author(s) 2020

\begin{abstract}
Aims Endocannabinoids are lipid mediators involved in the regulation of glucose homeostasis. They interact with the canonical cannabinoid receptors $\mathrm{CB}_{1}$ and $\mathrm{CB}_{2}$, and it is now apparent that some cannabinoid receptor ligands are also agonists at GPR55. Thus, $\mathrm{CB}_{1}$ antagonists such as SR141716A, also known as rimonabant, and AM251 act as GPR55 agonists in some cell types. The complex pharmacological properties of cannabinoids make it difficult to fully identify the relative importance of $\mathrm{CB}_{1}$ and GPR55 in the functional effects of SR141716A, and AM251. Here, we determine whether SR141716A and AM251 regulation of mouse and human islet function is through their action as GPR55 agonists.

Methods Islets isolated from $\mathrm{Gpr} 55^{+/+}$and $\mathrm{Gpr} 55^{-/-}$mice and human donors were incubated in the absence or presence of $10 \mu \mathrm{M}$ SR141716A or AM251, concentrations that are known to activate GPR55. Insulin secretion, cAMP, IP ${ }_{1}$, apoptosis and $\beta$-cell proliferation were quantified by standard techniques.

Results Our results provide the first evidence that SR141716A and AM251 are not GPR55 agonists in islets, as their effects are maintained in islets isolated from $\mathrm{Gpr} 55^{-/-}$mice. Their signalling through $\mathrm{G}_{\mathrm{q}}$-coupled cascades to induce insulin secretion and human $\beta$-cell proliferation, and protect against apoptosis in vitro, indicate that they have direct beneficial effects on islet function.

Conclusion These observations may be useful in directing development of peripherally restricted novel therapeutics that are structurally related to SR141716A and AM251, and which potentiate glucose-induced insulin secretion and stimulate $\beta$-cell proliferation.
\end{abstract}

Keywords Islets $\cdot$ Cannabinoids $\cdot \beta$-Cell function $\cdot$ Insulin secretion $\cdot$ Apoptosis $\cdot$ Proliferation

\begin{tabular}{|c|c|c|c|c|}
\hline \multirow{4}{*}{\multicolumn{2}{|c|}{$\begin{array}{l}\text { Abbreviations } \\
\mathrm{AM} 251\end{array}$}} & & BrdU & Bromodeoxyuridine \\
\hline & & 1-(2,4-Dichlorophenyl)- & & (5-bromo-2'-deoxyuridine) \\
\hline & & 5-(4-iodophenyl)-4-methyl- & Cch & Carbachol \\
\hline & & $\begin{array}{l}N \text {-(piperidin-1-yl)-1H-pyra- } \\
\text { zole-3-carboxamide }\end{array}$ & $\mathrm{CB}_{1}$ & $\begin{array}{l}\text { Canonical cannabinoid recep- } \\
\text { tor type } 1\end{array}$ \\
\hline \multirow{3}{*}{\multicolumn{2}{|c|}{$\begin{array}{l}\text { BMI } \\
\text { Bp }\end{array}$}} & Body Mass Index & $\mathrm{CB}_{2}$ & Canonical cannabinoid recep- \\
\hline & & Base pair & & tor type 2 \\
\hline & & & CMRL & Connaught Medical Research \\
\hline \multirow{3}{*}{\multicolumn{3}{|c|}{$\begin{array}{l}\text { Electronic supplementary material The online version of this } \\
\text { article (https://doi.org/10.1007/s00018-019-03433-6) contains } \\
\text { supplementary material, which is available to authorized users. }\end{array}$}} & & Laboratories \\
\hline & & & $\mathrm{Ct}$ & Cycle threshold \\
\hline & & & DAPI & 4',6-Diamidino-2-phenylin- \\
\hline & $\begin{array}{l}\text { Inmaculada } \mathrm{Ru} \\
\text { inmaculada.ruz }\end{array}$ & $@$ kcl.ac.uk & GLP-1 & $\begin{array}{l}\text { dole } \\
\text { Glucagon-like peptide-1 }\end{array}$ \\
\hline & & & GPR55 & G-protein-coupled receptor \\
\hline \multicolumn{3}{|c|}{$\begin{array}{l}\text { Shanta J. Persaud } \\
\text { shanta.persaud@kcl.ac.uk }\end{array}$} & & 55 \\
\hline \multirow{2}{*}{1} & & & $\mathrm{G}_{\mathrm{q}}$ & $\mathrm{G}_{\mathrm{q}}$ alpha subunit \\
\hline & Department of & nool of Life Course Sciences, & $\mathrm{G}_{\mathrm{s}}$ & $\mathrm{G}_{\mathrm{s}}$ alpha subunit \\
\hline
\end{tabular}




$\begin{array}{ll}\text { HTRF } & \begin{array}{l}\text { Homogeneous time resolved } \\ \text { fluorescence }\end{array} \\ & \text { Inositol-1-phosphate } \\ \mathrm{IP}_{1} & \text { Inositol trisphosphate } \\ \mathrm{IP}_{3} & \text { 5-(4-Chlorophenyl)-1-(2,4- } \\ \text { LH-21 } & \text { dichlorophenyl)-3-hexyl-1H- } \\ & \text { 1,2,4-triazole } \\ & \text { Muscarinic receptors } \\ \mathrm{M}_{3} & \text { Roswell Park Memorial } \\ \text { RPMI } & \text { Institute } \\ & \text { 5-(4-Chlorophenyl)-1-(2,4- } \\ \text { SR141716A (rimonabant) } & \text { dichloro-phenyl)-4-methyl- } \\ & N \text {-(piperidin-1-yl)-1H-pyra- } \\ & \text { zole-3-carboxamide }\end{array}$

\section{Introduction}

The intracellular signalling network that regulates glucosestimulated insulin secretion from islet $\beta$-cells is extraordinarily complex and multifactorial. Insulin secretion is modulated by nutrients, incretin hormones, neurotransmitters and other secreted factors [1], including endocannabinoids. Endocannabinoids are mediators that are synthesised on demand from membrane phospholipids. They can regulate glucose homeostasis through interaction with the canonical cannabinoid $(\mathrm{CB})$ receptors, $\mathrm{CB}_{1}$ and $\mathrm{CB}_{2}$, and with other cannabinoid-responsive G-protein-coupled receptors (GPCRs), such as G-protein-coupled receptor 55 (GPR55) [2-4]. CB $_{1}$ and GPR55 receptors are abundantly expressed in the hypothalamus, where centers regulating energy homeostasis are located, and peripherally in liver, muscle, adipose tissue, gastrointestinal tract and $\beta$-cells $[2$, $3,5]$. In contrast, although $\mathrm{CB}_{2}$ receptors are also present in the central nervous system and endocrine pancreas, they are mainly expressed in cells and organs of the immune system [6], where endocannabinoids mediate immunomodulatory actions.

The role of endocannabinoids in appetite regulation has been extensively studied over the past 20 years $[7,8]$. In particular, the $\mathrm{CB}_{1}$ receptor was considered to be a promising pharmacological target for weight management due to its activation being associated with hedonic feeding behavior. Rimonabant (SR141716A; Suppl. Fig. S1A) was the first selective antagonist described for $\mathrm{CB}_{1}$ receptors in in vitro and in vivo studies [9-11], and it was introduced into clinical use in 2006 as an anti-obesity agent. Rimonabant use was associated with reductions in body weight and waist circumference, and improvements in the profile of metabolic risk factors in patients who were overweight or obese and had atherogenic dyslipidemia [12-15]. Despite being withdrawn due to its adverse psychological effects, almost half of the metabolic benefits, including elevations in circulating adiponectin, occurred independent of weight loss, suggesting direct peripheral effects of this compound [16]. The effects of SR141716A to improve glucose tolerance in obese animal models $[17,18]$ and humans $[19,20]$ are likely to have been due, at least in part, to its ability to improve insulin sensitivity, but it is also possible that direct stimulatory effects on islets could contribute to the reductions in blood glucose levels. However, observations of potentiation of glucose-induced insulin secretion by $\mathrm{CB}_{1}$ agonists [21, 22] suggest that antagonism of $\beta$-cell $\mathrm{CB}_{1}$ receptors is unlikely to be responsible for the beneficial effects of SR141716A on glucose homeostasis. It is known that both SR141716A and its iodo analogue, AM251 (Suppl. Fig. S1B), can act as GPR55 agonists in some cell types [23-26]. We have previously reported that AM251 directly stimulated insulin secretion from human islets [21], and a neutral $\mathrm{CB}_{1}$ antagonist, $\mathrm{LH}-21$, potentiated insulin release, $\mathrm{Ca}^{2+}$ signalling and $\beta$-cell survival by acting as a GPR55 agonist in isolated human and mouse islets [4]. It is therefore possible that AM251 and SR141716A have stimulatory effects in islets as GPR55 agonists, rather than $\mathrm{CB}_{1}$ antagonists.

In the present study we have therefore evaluated the effects of SR141716A and AM251 on insulin secretion, cAMP and $\mathrm{IP}_{1}$ levels, apoptosis and proliferation in human and mouse islets, and we used islets isolated from Gpr $55^{-/-}$mice to determine the requirement for GPR55 in these effects.

\section{Materials and methods}

\section{Reagents}

Culture media and supplements, collagenase type XI, histopaque-1077, DMSO, EDTA, IBMX, carbachol, clonidine, $\mathrm{LiCl}$, exendin-4, forskolin, agarose, bionic buffer and BSA were obtained from Sigma-Aldrich (Dorset, UK). DNeasy Blood and Tissue, RNeasy Mini and QuantiTect SYBR Green PCR kits and qPCR primers for mouse and human $\mathrm{CB}_{1}$ (CNR1), GPR119, GPR18, GPR92 (LPAR5), delta-opioid receptor (OPRD1), transient receptor potential cation channel subfamily V member 1 (TRPVI), GPR3, GPR6, GPR12, and ACTB were from Qiagen (Manchester, UK). PCR primers for Gpr55 genotyping were from Eurofins Genomics (Wolverhampton, UK). SR141716A was from Tocris Bioscience (Abingdon, UK). AM251 and rabbit anti-Ki67 primary antibody were from Abcam (Cambridge, UK). cAMP HiRange and IP-one ( IP $_{1}$ ) assays were from Cisbio (Codolet, France). TaqMan RT-PCR kit, 100 base pairs (bp) DNA ladder, SYBR ${ }^{\circ}$ DNA gel stain, HEPES, HBSS and DAPI were from Thermo Fisher Scientific (Paisley, UK). Caspase-Glo 3/7 and GoTaq ${ }^{\circledR}$ G2 Green Master Mix were from Promega (Southampton, UK). 
Recombinant TNF $\alpha$, IFN $\gamma$ and IL- $1 \beta$ were from PeproTech EC (London, UK). Guinea pig anti-insulin was obtained from Dako (Cambridge, UK). AlexaFluor 488- and AlexaFluor 594-conjugated secondary antibodies were from Jackson ImmunoResearch Laboratories (Newmarket, UK).

\section{Animals}

A colony of C57BL/6J Gpr55 homozygous knockout mice $\left(\mathrm{Gpr} 55^{-/-}\right)$was maintained at King's College London, with ad libitum access to food and water [3]. Agematched wild-type $\left(G p r 55^{+/+}\right)$male C57BL/6J mice were purchased from Envigo (Bicester, UK) and maintained in the same conditions as the Gpr $55^{-/-}$mice prior to islet isolation. All animal procedures were approved by the King's College London Ethics Committee and carried out in accordance with the UK Home Office Animals (Scientific Procedures) Act 1986.

\section{Genotyping}

Ear biopsies were removed from weaned mice and DNA samples were prepared using the Qiagen DNeasy Blood and Tissue Kit following the manufacturer's instructions. DNA was amplified by PCR using 35 cycles with Gpr55 primers $\left(94{ }^{\circ} \mathrm{C}: 60 \mathrm{~s}, 55^{\circ} \mathrm{C}: 60 \mathrm{~s}, 72{ }^{\circ} \mathrm{C}: 60 \mathrm{~s}\right.$; forward: $5^{\prime} \mathrm{TCT}$ GGATTCATCGACTGTG3', reverse 1: 5'TCCACAATC AAGCTG3', reverse 2: 5'GTCACCCATCCAGGTGAT3'. Products were fractionated by gel electrophoresis $(150 \mathrm{~V}$, $40 \mathrm{~min}$ ) using $1.8 \%$ agarose in bionic buffer, with predicted amplicons of 207 base pairs for wild-type mice and 299 base pairs for transgenic mice [27].

\section{Isolation of mouse and human islets}

Islets were isolated from 8-12-week-old male

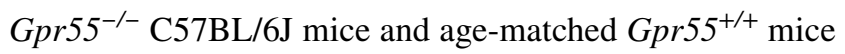
by collagenase digestion of the exocrine pancreas [28], yielding $\sim 350$ islets per mouse. Human islets used for functional studies and qPCR were isolated from 14 and 3 nondiabetic (Suppl. Table S1), heart-beating pancreas donors at the King's College Hospital Islet Transplantation Unit with appropriate ethical approval [29]. The average age $( \pm$ SEM $)$ of the donors for functional studies was $45 \pm 2.8$ years and the body mass index (BMI) was $28.4 \pm 1.3 \mathrm{~kg} / \mathrm{m}^{2}$, while islets used for qPCR were from donors with average age of $49 \pm 4.1$ years and BMI of $22.7 \pm 1.3 \mathrm{~kg} / \mathrm{m}^{2}$. Isolated mouse and human islets were maintained in culture overnight (mouse: RPMI-1640; human: CMRL-1066) at $37{ }^{\circ} \mathrm{C}, 95 \%$ air/5\% $\mathrm{CO}_{2}$ before experimental use [30].

\section{Dynamic insulin secretion}

Groups of 45 mouse or 55 human islets were perifused at a flow rate of $0.5 \mathrm{~mL} / \mathrm{min}$ with a physiological salt solution [31] supplemented with $2 \mathrm{mM}$ or $20 \mathrm{mM}$ glucose in the absence or presence of compounds of interest using a temperature-controlled perifusion system [30]. Perifusate fractions were collected at 2 min intervals and secreted insulin was quantified by radioimmunoassay [32]. SR141716A and AM251 were dissolved to $10 \mu \mathrm{M}$ in DMSO, such that the final DMSO concentration was $0.1 \%$, which was also used for control (vehicle) perifusions.

\section{RNA extraction and quantitative real-time PCR}

Total RNA was extracted from groups of $350 \mathrm{Gpr} 55^{+/+}$or Gpr $55^{-/-}$mouse islets or human islets using the Qiagen RNeasy Minikit according to the manufacturer's instructions and quantified using a NanoDrop spectrophotometer. $500 \mathrm{ng}$ of islet total RNA from mouse and human islets with $\mathrm{A}_{260} /$ $\mathrm{A}_{280}$ ratios between 1.8 and 2.2 were reverse-transcribed into cDNAs using the TaqMan RT-PCR kit. Quantitative realtime PCR (qPCR) using islet cDNAs was performed on a Lightcycler 480 to quantify expression of genes encoding $\mathrm{CB}_{1}$, GPR119, GPR18, GPR92, OPRD1, TRPV1, GPR3, GPR6 and GPR12 and levels were normalised to Actb/ACTB mRNA expression in the same samples. All GPCR and reference gene primer efficiency $(E)$ values were in the range of 1.85-2.15. For all gene quantifications, template cDNAs were diluted in such a way that all quantified genes returned cycle threshold $(\mathrm{Ct})$ values $<30$. The relative expression ratio of the targeted genes was calculated based on the $E$ and $\mathrm{Ct}$ deviation of the employed mouse/human islet preparations, and levels were normalised to Actb/ACTB expression in the same samples. Genes expressed $<0.001 \%$ of the mean mRNA level of the reference gene used were considered to be present only at trace level, as their expression was less than the lower limit of linear quantification of the QuantiTect primer assays. The primers used for qPCR amplifications are listed in Suppl. Table S2.

\section{$\mathrm{IP}_{1}$ and cyclic AMP accumulation}

Groups of five mouse islets or seven human islets were transferred to white-walled 96-well plates in HBSS supplemented with $10 \mathrm{mM}$ HEPES, $0.2 \%$ BSA, $5.6 \mathrm{mM}$ glucose and $2 \mathrm{mM}$ IBMX for quantification of cAMP or $50 \mathrm{mM} \mathrm{LiCl}$ for assay of $\mathrm{IP}_{1}$ levels. For cAMP measurements, islets were incubated for $1 \mathrm{~h}$ at room temperature in the absence or presence of $10 \mu \mathrm{M}$ SR $141716 \mathrm{~A}$ or AM251 using $20 \mathrm{nM}$ exendin-4 as a positive control to induce $G_{s}$ activation. For determination of $G_{i}$ activation, $1 \mu \mathrm{M}$ forskolin was added to the solutions to stimulate cAMP production so that the inhibitory effect 
of agents on cAMP generation could be detected. $1 \mu \mathrm{M}$ of the $\alpha_{2}$ agonist clonidine was used as a control $\mathrm{G}_{\mathrm{i}}$-coupled ligand. For $\mathrm{IP}_{1}$ accumulation, islets were incubated for $1 \mathrm{~h}$ at $37^{\circ} \mathrm{C}$ in the absence or presence of test agents and $500 \mu \mathrm{M}$ of the muscarinic agonist carbachol was used as a control $\mathrm{G}_{\mathrm{q}}$-coupled ligand. Following the subsequent assay steps according to the manufacturer's protocols, islet cAMP or $\mathrm{IP}_{1}$ levels were quantified by measuring the fluorescence emission intensity ratio at $665 / 620 \mathrm{~nm}$ using a Pherastar FS microplate reader (BMG Labtech Ltd, Aylesbury, UK).

\section{Caspase 3/7 activities}

Groups of five mouse or human islets were maintained in culture for $24 \mathrm{~h}$ in the absence or presence of $10 \mu \mathrm{M}$ SR141716A or $10 \mu \mathrm{M}$ AM251, then incubated for a further $20 \mathrm{~h}$ in RPMI-1640 with 2\% FBS (mouse) or CMRL with $0.2 \%$ albumin (human), in the absence or presence of a cytokine cocktail $(0.025 \mathrm{U} / \mu \mathrm{L}$ IL- $1 \beta, 1 \mathrm{U} / \mu \mathrm{L}$ TNF $\alpha$, and $1 \mathrm{U} / \mu \mathrm{L}$ IFN $\gamma$ ). Islet cell apoptosis was determined using the Caspase-Glo 3/7 assay [30].

\section{Islet $\beta$-cell proliferation}

Groups of 250 mouse or human islets were incubated for $48 \mathrm{~h}$ at $37{ }^{\circ} \mathrm{C}\left(95 \%\right.$ air $\left./ 5 \% \mathrm{CO}_{2}\right)$ in RPMI-1640 with $2 \%$ FBS (mouse) or CMRL with $0.2 \%$ albumin (human), supplemented with $10 \mu \mathrm{M}$ SR141716A, $10 \mu \mathrm{M}$ AM251 or vehicle $(0.0001 \% \mathrm{DMSO})$. Islets were then pelleted at $135 \mathrm{~g}$, fixed with $4 \%$ paraformaldehyde and embedded in paraffin. Sections of $5 \mu \mathrm{m}$ thickness were dewaxed, then antigens were retrieved using citrate buffer $(10 \mathrm{mM}$ citric acid, $0.05 \%$ Tween 20, pH 6.0). Sections were incubated overnight at $4{ }^{\circ} \mathrm{C}$ with primary anti-insulin (guinea pig) and anti-Ki67 (rabbit) antibodies at 1:200 dilution, then incubated with anti-guinea pig AlexaFluor 594 and anti-rabbit AlexaFluor 488 antibodies (1:150 dilution) for $1 \mathrm{~h}$ at room temperature. The primary and secondary antibodies are listed in Suppl. Table S3. Images were visualized using a Nikon A1 Inverted Confocal microscope and analysed blindly before quantification using Fiji Image J software (https://fiji.sc) [4]. For each experiment, the images were acquired with the same settings and histological quantifications were performed in paraffin sections that had been immunostained under the same conditions.

\section{Statistical analyses}

Data are shown as mean \pm SEM. GraphPad Prism 8.0 (GraphPad Software, Inc.) was used for statistical analyses. Comparisons were analysed by unpaired Student's $t$ test, Wilcoxon signed-rank test and one-way or two-way ANOVA with repeated measures followed by post-hoc tests, as appropriate. $P<0.05$ was considered statistically significant.

\section{Results}

\section{SR141716A and AM251 stimulate insulin secretion from human islets}

Dynamic perifusions of isolated human islets indicated that SR141716A initiated insulin secretion at $2 \mathrm{mM}$ glucose and it also potentiated glucose-stimulated insulin secretion (Fig. 1a, c and d), and similar stimulatory effects were observed when human islets were exposed to the SR141716A structural analogue, AM251 (Fig. 1b, e and f). These effects on insulin secretion showed a rapid onset and they were readily reversible upon removal of SR141716A or AM251.

\section{SR141716A and AM251 increase insulin secretion through a GPR55-independent mechanism}

SR141716A and AM251 were initially classified as selective $\mathrm{CB}_{1}$ receptor antagonists/inverse agonists but they also show GPR55 agonist activities in the micromolar range [23, 33 ] and we have recently reported that another $\mathrm{CB}_{1}$ neutral antagonist/inverse agonist, LH-21, stimulated insulin secretion through GPR55-dependent signalling [4]. The ability of SR141716A and AM251 to act via GPR55 in $\beta$-cells was investigated by quantifying their effects on insulin secretion from islets isolated from $\mathrm{Gpr} 55^{+/+}$and $\mathrm{Gpr} 55^{-/-}$mice. In these experiments $10 \mu \mathrm{M}$ SR141716A significantly stimulated insulin secretion at 2 and $20 \mathrm{mM}$ glucose in islets from $\mathrm{Gpr} 55^{+/+}$mice, and it had similar stimulatory effects in islets isolated from $\mathrm{Gpr} 55^{-/-}$mice (Fig. 2a). Calculation of AUC data indicated that there was no statistically significant difference in the responses to $10 \mu \mathrm{M}$ SR141716A in $\mathrm{Gpr}_{55^{+/+}}$and $\mathrm{Gpr} 55^{-/-}$islets at either $2 \mathrm{mM}$ or $20 \mathrm{mM}$ glucose (Fig. 2c, d). AM251 $(10 \mu \mathrm{M})$ also potentiated insulin secretion from islets of both genotypes, but it did not significantly stimulate basal insulin secretion (Fig. 2b). As for SR141716A, the effects of AM251 on insulin secretion were not significantly altered by deletion of GPR 55 , calculated by AUC (Fig. 2e, f).

\section{Expression of other islet cannabinoid receptors}

In an attempt to identify possible receptors through which SR141716A and AM251 could mediate their functional effects, mRNAs encoding the cannabinoid-responsive GPCRs Cnrl ( $\mathrm{CB}_{1}$ ), Gpr119, Gpr18, Lpar5 (GPR92), Oprd1, Gpr3, Gpr6 and Gpr12 and the non-selective channel Trpv 1 were quantified by qPCR using cDNA samples 
(A)

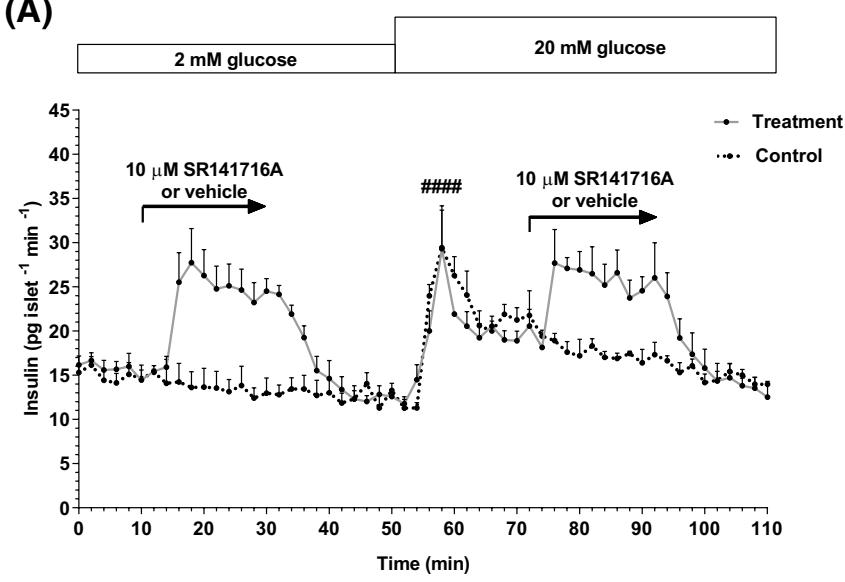

(C)

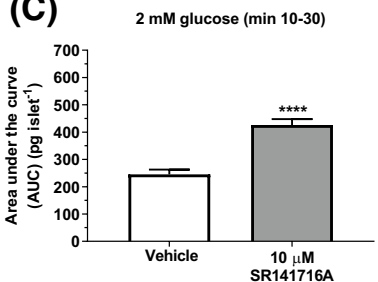

(D) $20 \mathrm{mM}$ glucose (min 70-90)

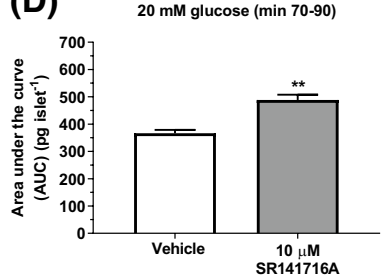

Fig. 1 Effects of SR141716A and AM251 on dynamic insulin secretion from human islets. Profiles of insulin secretion from islets isolated from human donors over time (0-110 $\mathrm{min})(\mathbf{a}, \mathbf{b})$ and total insulin AUC (pg islet $\left.{ }^{-1}\right)$ in the absence and presence of SR141716A (c, d) and $10 \mu \mathrm{M} \mathrm{AM} 251(\mathbf{e}, \mathbf{f})$ at $2 \mathrm{mM}$ glucose (c, e) and $20 \mathrm{mM}$ glucose (d, f). $10 \mu \mathrm{M}$ SR141716A (a, c and d) and $10 \mu \mathrm{M}$ AM251 (b, e and f) significantly stimulated insulin secretion from human islets at 2 and $20 \mathrm{mM}$ glucose. Data are mean + SEM representative of three

from $G p r 55^{+/+}$and $G p r 55^{-/-}$mouse islets. It can be seen from Fig. 3 that Cnr1, Gpr119, Gpr18, Lpar5, Trpv1 and Gpr6 mRNAs were readily detectable in mouse islets, while Gpr3 and Gpr12 were expressed at only trace levels and Oprdl was not detected. Lpar5 and Trpv1 mRNAs were significantly upregulated in islets isolated from $\mathrm{Fpr}_{55^{-/-}}$mice, as was expression of $\mathrm{Cnrl}$ mRNA. Conversely, Gprl19 mRNA levels in islets were reduced following GPR55 deletion, and there was no significant change in Gprl8 or Gpr6 expression. We also quantified expression of these receptors in human islets and found that expression levels of $C N R I$ and GPR 119 were significantly lower in human islets than in wildtype mouse islets; LPAR5 and TRPVI expression levels were similar between mouse and human islets, and while GPR18 and OPRD1 were present and absent in mouse islets, respectively, the opposite was true in human islets (Fig. 3).

\section{SR141716A and AM251 do not modulate islet CAMP levels}

The possibility that the inverse agonist activity of SR141716A and AM251 at islet $\mathrm{CB}_{1}$ receptors or their
(B)

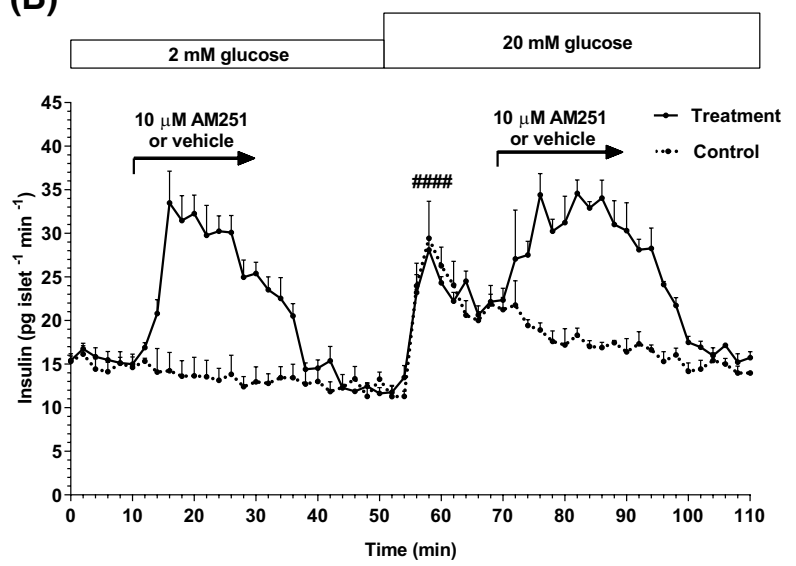

(E)

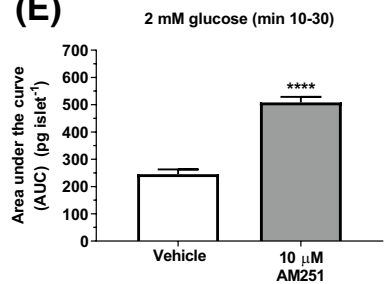

(F)

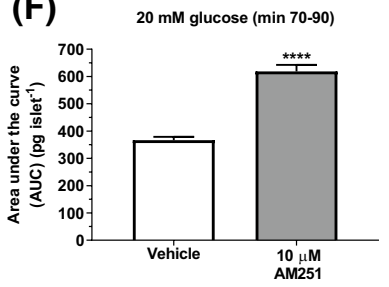

separate experiments, each of four replicates, 55 islets per channel.

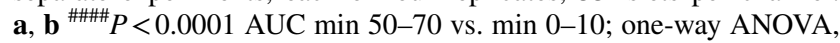
Tukey's multiple comparisons post test; c $* * * * P<0.0001$ AUC min 10-30 vehicle vs. SR141716A; d $* * P<0.01$ AUC min 70-90

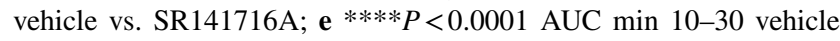
vs. AM251; f $* * * * P<0.0001$ AUC min $70-90$ vehicle vs. AM251; unpaired $t$ test

activation of a $\mathrm{G}_{\mathrm{s}}$-coupled GPCR such as GPR119 could lead to activation of adenylyl cyclase and increase cAMP levels [34] was investigated, to determine if this could explain the stimulatory effects of these ligands on insulin secretion and their independence of signalling via GPR55. However, cAMP quantification indicated that neither ligand had a stimulatory effect on basal or forskolin-stimulated cAMP levels in islets isolated from $\mathrm{Fpr} 5^{+/+}$(Fig. 4a, d) or Gpr55 $5^{-/}$(Fig. 4b, e) mice, or in human islets (Fig. 4c, f). In these experiments the GLP-1 agonist exendin-4 caused the expected increase in cAMP in both mouse and human islets, and the $\alpha_{2}$-adrenergic agonist clonidine significantly inhibited forskolin-induced elevation in cAMP (Fig. 4).

\section{SR141716A and AM251 increase islet IP 1 levels}

As elevations in $\mathrm{Ca}^{2+}$ are required for the exocytotic release of insulin and islets express $\mathrm{G}_{\mathrm{q}}$-coupled putative cannabinoid receptors we investigated the effects of SR141716A and AM251 on $\mathrm{G}_{\mathrm{q}}$ coupling in islets by quantification of the stable $\mathrm{IP}_{3}$ metabolite, $\mathrm{IP}_{1}$. Both ligands significantly increased $\mathrm{IP}_{1}$ levels in mouse (Fig. 5a) and 


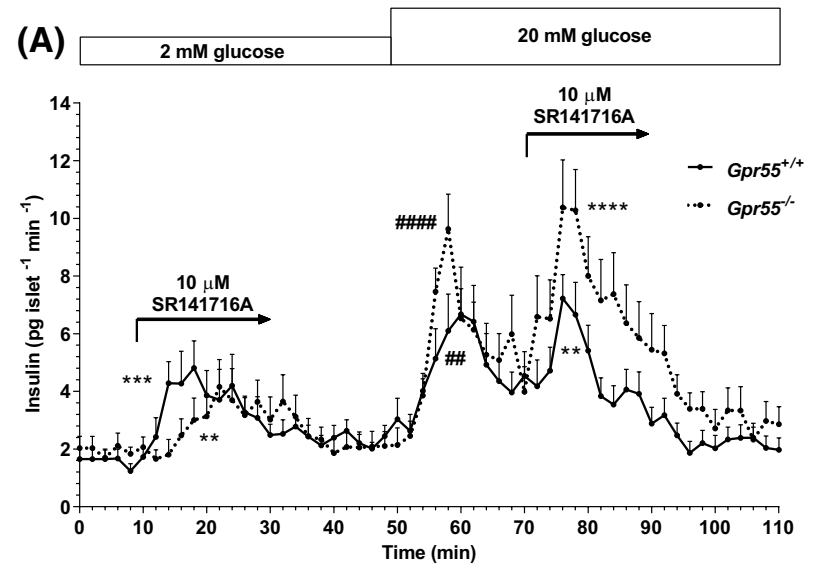

(C)

(D) $\quad 10 \mu \mathrm{M}$ SR141716A $(\min 70-90)$
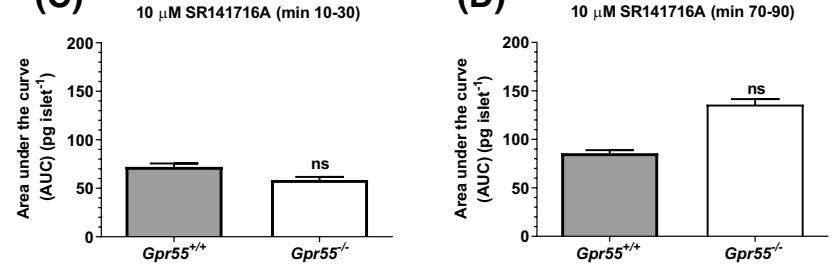

Fig. 2 Effects of SR141716A and AM251 on dynamic insulin secretion from mouse islets. Profiles of insulin secretion from islets isolated from $\mathrm{Gpr} 55^{+/+}$(continuous line) and $\mathrm{Fpr}^{-/-}$(dashed line) mice over time $(0-110 \mathrm{~min})(\mathbf{a}, \mathbf{b})$ and total insulin AUC $\left(\mathrm{pg}_{\text {islet }}{ }^{-1}\right)$ of the intervals 10-30 $\min (\mathbf{c}, \mathbf{e})$ and 70-90 $\min (\mathbf{e}, \mathbf{f})$ between both genotypes. $10 \mu \mathrm{M}$ SR141716A (a) and $10 \mu \mathrm{M}$ AM251 (b) significantly potentiated the plateau phase of glucose-stimulated insulin secretion in islets from both genotypes, with no statistical differences (ns) between the responses (d, f). $10 \mu \mathrm{M}$ SR141716A also significantly increased insulin secretion at $2 \mathrm{mM}$ glucose in islets from $G p r 55^{+/+}$and $G p r 55^{-/-}$mice (a). Data are mean + SEM of five independent experiments, each of four replicates, 45 islets per channel.
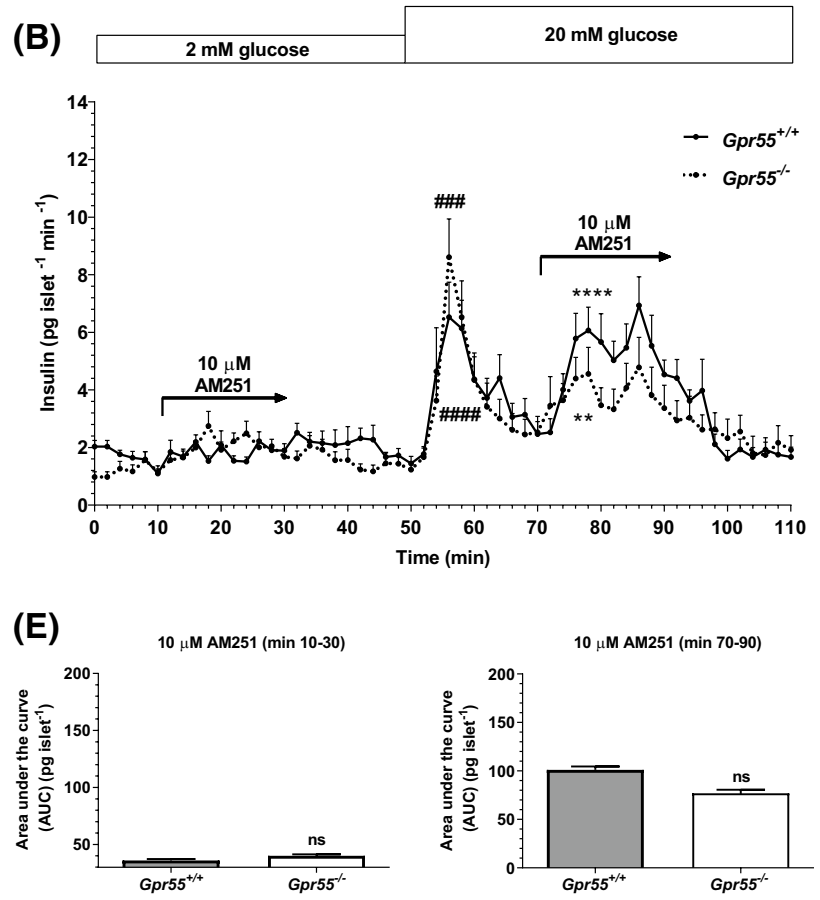

$\mathbf{a}^{\# \#} P<0.01$ AUC min $50-70$ WT vs. min $0-10 \mathrm{WT},{ }^{\# \# \#} P<0.0001$ AUC min 50-70 KO vs. min 0-10 KO, **P<0.01, AUC min 70-90 SR141716A WT vs. $\min 0-10 \mathrm{WT}, * * * * P<0.0001$, AUC min 70-90 SR141716A KO vs. min 0-10 KO; two-way ANOVA, Tukey's multiple comparisons post test; $* * * P<0.001$ AUC min 10-30 SR141716A WT vs. $\min 0-10 \mathrm{WT}, * * P<0.01$ AUC $\min 10-30$ SR141716A KO vs. min $0-10 \mathrm{KO}$, unpaired Student's $t$ test. b ${ }^{\# \# \#} P<0.001$ AUC min $50-70 \mathrm{KO}$ vs. min $0-10 \mathrm{KO},{ }^{\# \# \# \#} P<0.0001$ AUC min 50-70 WT vs. $\min 0-10 \mathrm{WT}, * * P<0.01$, AUC $\min 70-90$ AM251 KO vs. $\min 0-10$ $\mathrm{KO}, * * * * P<0.0001$, AUC $\min 70-90$ AM251 WT vs. min 0-10 WT; two-way ANOVA, Tukey's multiple comparisons post test

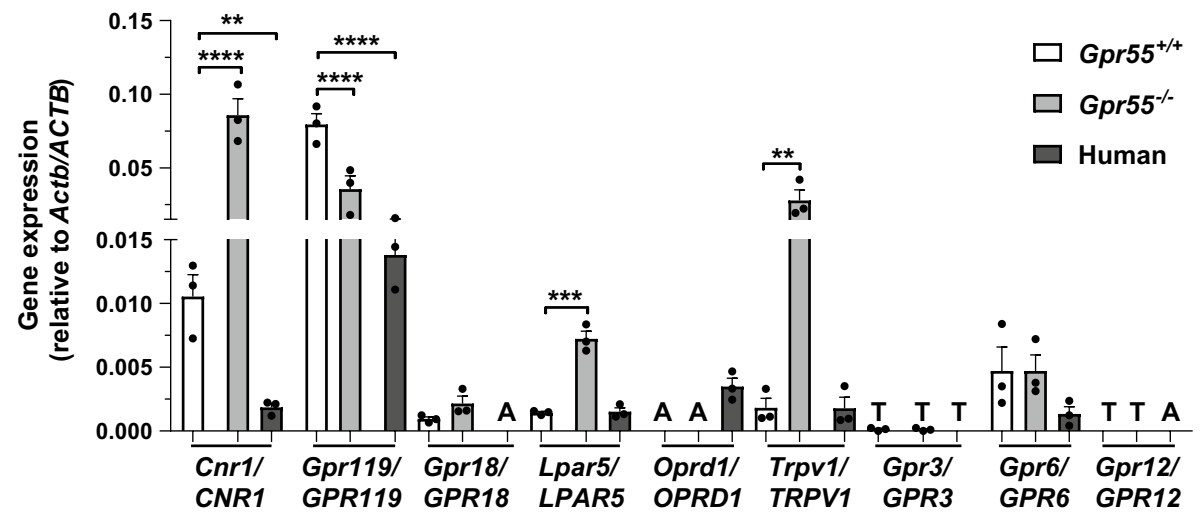

Fig. 3 Quantitative RT-PCR of Cnrl/CNR1, Gpr119/GPR119, Gpr18/GPR18, Lpar5/LPAR5, Oprd1/OPRD1, Trpv1/TRPV1, Gpr3/GPR3, Gpr6/GPR6, and Gpr12/GPR12 mRNA expression in $G p r 55^{+/+}$and $G p r 55^{-/-}$mouse and human islets relative to Actb/ ACTB mRNA. $* * P<0.01$; $* * * P<0.001 ; * * * * P<0.0001$. Data are expressed as mean + SEM of three non-pooled $G p r 55^{+/+}$and Gpr55 $55^{-/-}$mouse islet preparations (350 islets per mouse) and three non-pooled non-diabetic human islet preparations (1000 islets per preparation) and they were analysed by one-way ANOVA. A: mRNA absent (i.e., not detected), T: trace mRNA expression 

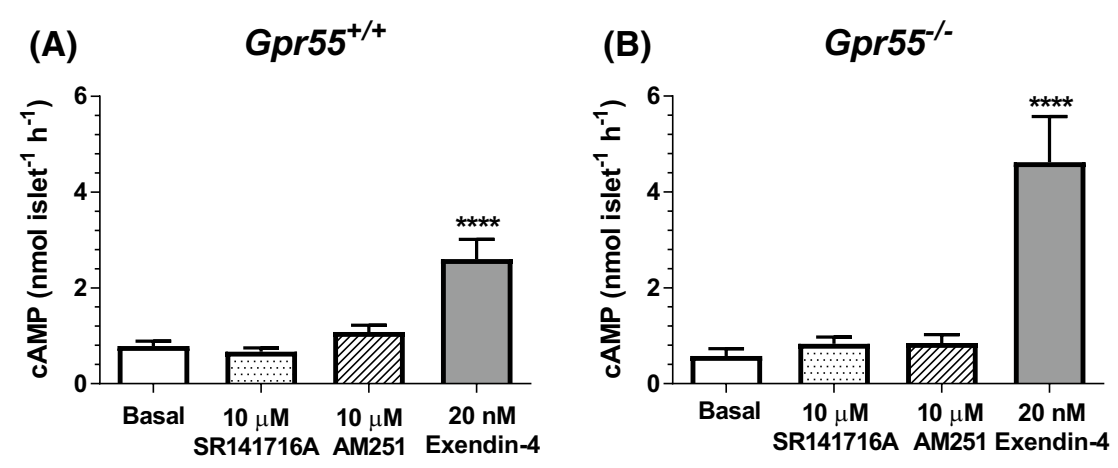

(C) Human islets
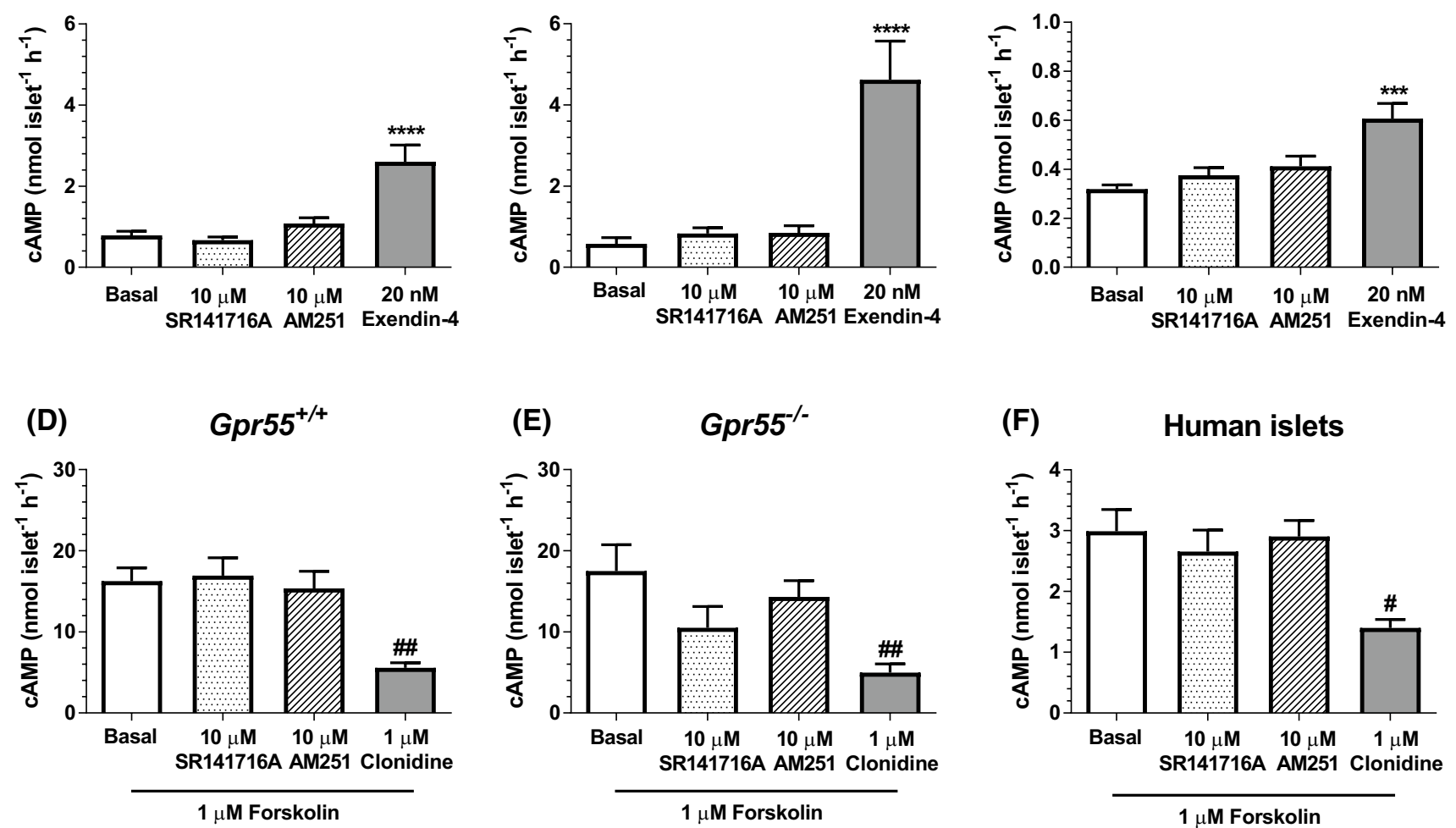

Fig. 4 Effects of SR141716A and AM251 on cAMP levels in mouse and human islets. $10 \mu \mathrm{M}$ SR141716A and AM251 had no effect on basal or forskolin-stimulated cAMP accumulation in islets from $G p r 55^{+/+}(\mathbf{a}, \mathbf{d})$ and $G p r 55^{-/-}(\mathbf{b}, \mathbf{e})$ mice or from human donors (c, f). Nevertheless, $20 \mathrm{nM}$ exendin- 4 and $1 \mu \mathrm{M}$ clonidine significantly increased and decreased cAMP, respectively $(\mathbf{a}-\mathbf{f})$. Data are expressed as mean \pm SEM of 4-6 replicates within five individual experiments. ${ }^{\#} P<0.05$ and ${ }^{\# \#} P<0.01$ clonidine vs. forskolin. $* * * P<0.001$ and $* * * * P<0.0001$ exendin- 4 vs. basal; data were analysed using one-way ANOVA, followed by Dunnett's multiple comparisons post test
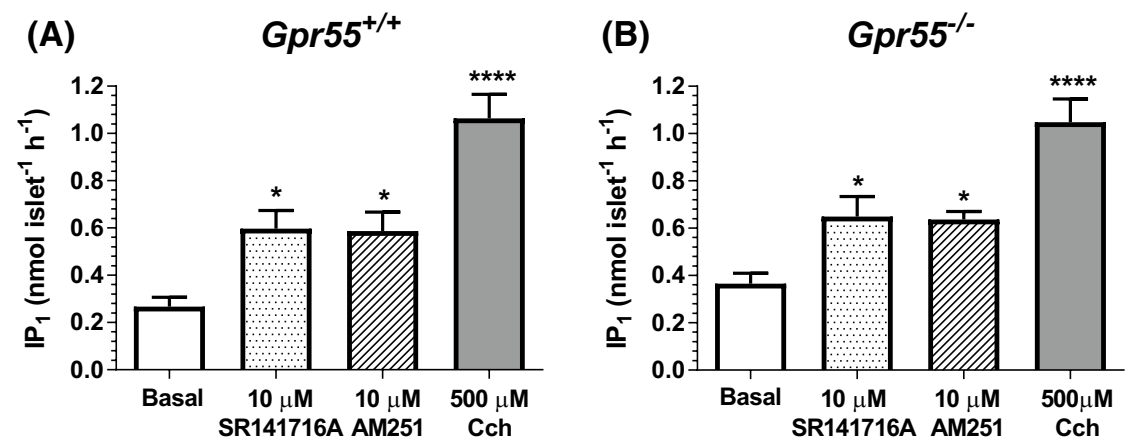

(C)

Human islets

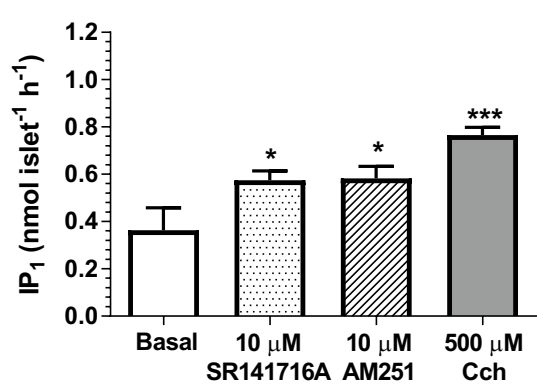

Fig. 5 Effects of SR141716A and AM251 on $\mathrm{G}_{\mathrm{q}}$ signalling in mouse and human islets. A-c $10 \mu \mathrm{M}$ SR141716A and AM251 significantly elevated $\mathrm{IP}_{1}$ levels in islets from $\mathrm{Gpr}_{55^{+/+}}$(a) and $\mathrm{Gpr} 55^{-/-}$mice (b) and human donors (c). $500 \mu \mathrm{M}$ Carbachol (Cch) was used as

human (Fig. 5c) islets, as did the muscarinic receptor agonist carbachol (Cch), which signals via $\mathrm{G}_{\mathrm{q}}$-coupled $\mathrm{M}_{3}$ receptors in islets [35]. Consistent with the maintenance of their stimulatory effects on insulin secretion in islets positive control. Data are expressed as mean \pm SEM of three separate experiments, each of 4-6 replicates. ${ }^{*} P<0.05$, basal vs. treatment; $* * * P<0.001, * * * * P<0.0001$, basal vs. Cch

from $\mathrm{Gpr} 55^{-/-}$mice, SR141716A and AM251 also significantly elevated $\mathrm{IP}_{1}$ in islets in which GPR55 had been deleted (Fig. 5b). 


\section{SR141716A and AM251 decrease mouse and human islet apoptosis}

Investigation of the effects of SR141716A and AM251 on caspase 3/7 activities in mouse and human islets indicated that both ligands significantly reduced apoptosis induced by $20 \mathrm{~h}$ exposure to a cocktail of inflammatory cytokines in islets isolated from $\mathrm{Gpr}_{55^{+/+}}$mice (Fig. 6a) and these anti-apoptotic effects were also observed in islets from Gpr55 $5^{-/-}$mice (Fig. 6b). In addition, SR141716A and AM251 totally blocked cytokine-induced apoptosis in human islets (Fig. 6c). However, although these compounds exerted protective effects against cytokines, they had no effect on basal levels of caspase activity in the absence of cytokines in either mouse or human islets.

\section{SR141716A and AM251 stimulate human $\beta$-cell proliferation}

Confocal fluorescence immunohistochemistry indicated that the low level of $\beta$-cell proliferation in vehicle-treated $G p r 55^{+/+}$and $\mathrm{Gpr} 55^{-/-}$mouse islets, identified through co-expression of insulin and the proliferative marker Ki67, was abolished when islets were incubated with $10 \mu \mathrm{M}$ SR141716A for $48 \mathrm{~h}$ (Fig. 7a, b). $10 \mu \mathrm{M}$ AM251 had similar effects to SR141716A and there was also a trend towards decreased islet area (Fig. 7c) and number of $\beta$-cells per islet (Fig. 7d) following $48 \mathrm{~h}$ exposure to $10 \mu \mathrm{M}$ SR141716A or $10 \mu \mathrm{M}$ AM251. In contrast, exposure of human islets to SR141716A or AM251 for $48 \mathrm{~h}$ induced significant increases in the small number of insulin-positive cells expressing
Ki67, indicative of increased human $\beta$-cell proliferation (Fig. 8a, b). Quantification of human islet confocal images indicated that the ligands also significantly increased islet area (Fig. 8c) and the number of $\beta$-cells per islet (Fig. 8d).

\section{Discussion}

The effects of SR141716A on insulin secretion in vitro and in vivo in rodents have been a point of controversy in the literature. Thus, it is reported to decrease insulin hypersecretion in islets isolated from diabetic rats [36] and glucose-induced insulin secretion from mouse islets [37], but another study showed that SR141716A did not significantly affect insulin secretion from mouse islets [38]. Conversely, SR141716A was found to reversibly stimulate insulin secretion from human islets [39], and its chronic administration improved islet function and morphology in diabetic rats [40]. The reasons for discrepancies between different studies are not immediately obvious, but in in vitro experiments with isolated islets stimulatory effects are more likely to be observed in dynamic perifusions [39] rather than in static incubations of islets [37], where potentially inhibitory paracrine mediators such as somatostatin and GABA may accumulate. The effects of the SR141716A analogue, AM251, on insulin secretion are more consistent, with reports that it has insulinotropic effects in mouse islets and BRINBD11 cells [41], in $\beta$ TC6 cells [42] and in human islets [21, 42]. Analysis of the functional effects of SR141716A and $\mathrm{AM} 251$ often focus on their classification as $\mathrm{CB}_{1}$ receptor antagonists/inverse agonists but they also act as GPR55
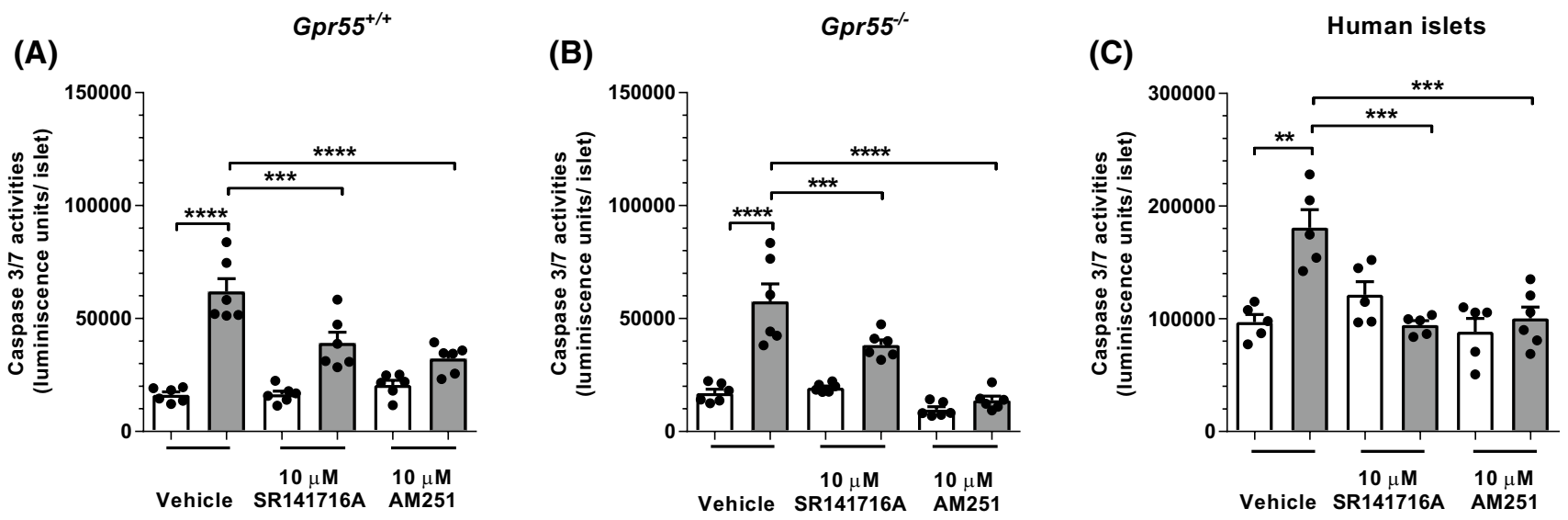

Fig. 6 Effects of SR141716A and AM251 on mouse and human islet apoptosis. Effects of $10 \mu \mathrm{M} \mathrm{SR} 141716 \mathrm{~A}$ and AM251 on apoptosis of $\mathrm{Gpr}^{55^{+/+}}$(a) and $\mathrm{Gpr} 55^{-/-}$(b) islets and human (c) islets after $20 \mathrm{~h}$ of culture in the absence or presence of a cytokine cocktail (grey bars). Apoptosis was detected by luminescence assay of caspase 3/7 activities. Data are expressed as mean + SEM representative of five independent experiments for both mouse and human islets, each of 6-8 replicates. $* * P<0.01, * * * P<0.001, * * * * P<0.0001$. Data were analysed using one-way ANOVA with repeated measures, followed by Tukey's multiple comparison post test 
(A)
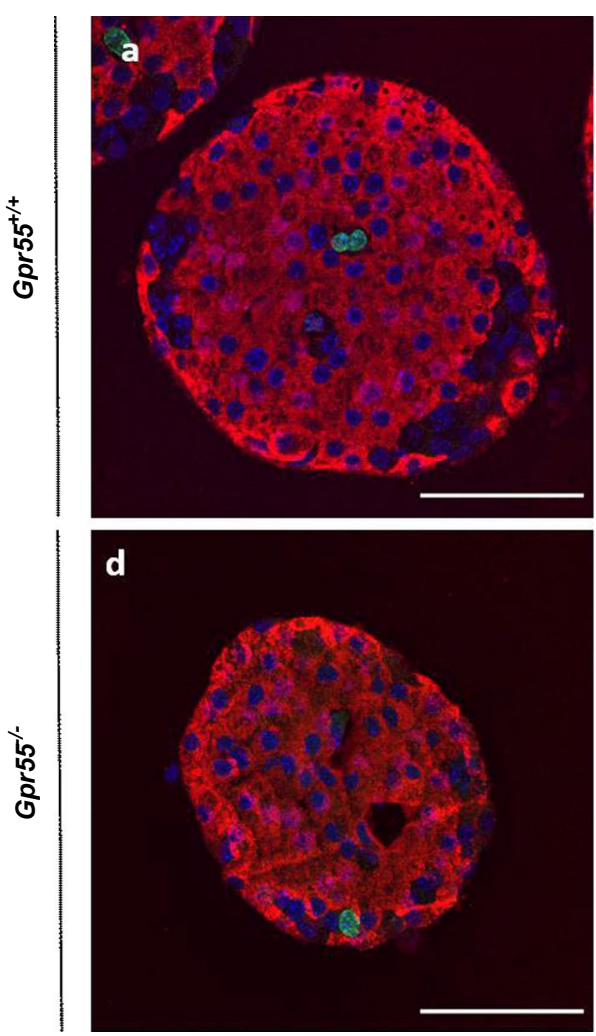

$10 \mu \mathrm{M}$ SR141716A
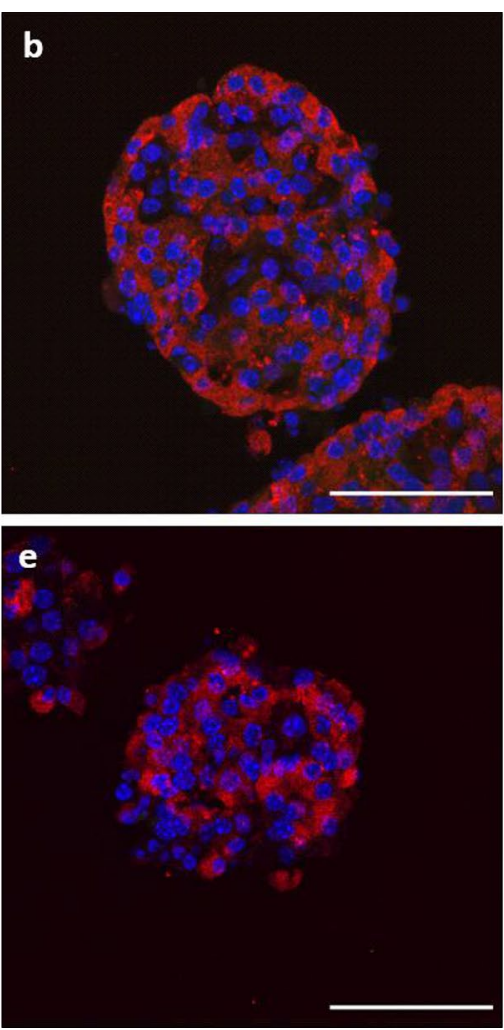

$10 \mu \mathrm{M}$ AM251

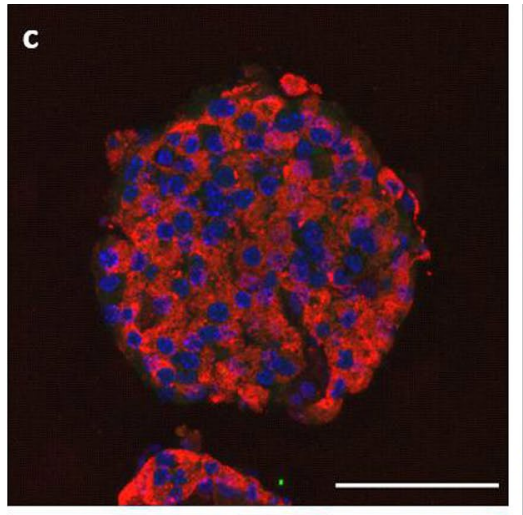

f

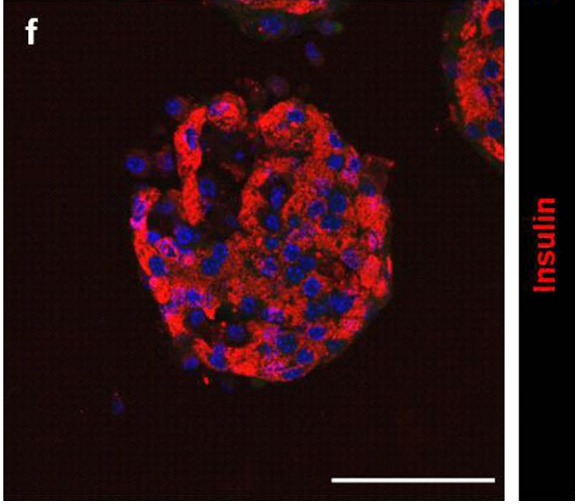

Fig. 7 Effects of SR141716A and AM251 on mouse $\beta$-cell proliferation. Representative confocal images of paraffin-embedded sections of islets from $\mathrm{Gpr} 55^{+/+}$and $\mathrm{Gpr} 55^{-/-}$mice probed with antibodies directed against insulin (red) and Ki67 (green), and DAPI staining (nuclei; blue) after maintenance of islets in culture for $48 \mathrm{~h}$ in the absence or presence of $10 \mu \mathrm{M}$ SR141716A or AM251 (a). Scale $b a r=50 \mu \mathrm{m}$. Post-acquisition analyses were performed with Fiji Image $\mathbf{J}$ software and are shown in $\mathbf{b}-\mathbf{d}$ : $\mathbf{b}$ number of Ki67- and

agonists in some cell types [23-26], with $\mathrm{EC}_{50}$ values of $3.9 \mu \mathrm{M}$ and $9.6 \mu \mathrm{M}$, respectively [33]. Experiments in which $10 \mathrm{mg} / \mathrm{kg}$ SR141716A was delivered to mice indicate that it reached $1.9 \mu \mathrm{g} / \mathrm{mL} 1 \mathrm{~h}$ after i.p administration, equivalent to $4.1 \mu \mathrm{M}$ in plasma [43], a concentration that is sufficient to induce activity at GPR55 in vivo. GPR55 is expressed by islet $\beta$-cells, with its activation enhancing glucose-induced insulin secretion [3-5, 41] so it is possible that the stimulatory effects of SR141716A and AM251 on insulin release could be mediated via their agonist action at $\beta$-cell GPR55. Thus, in the current study we investigated the effects of these ligands on insulin secretion, $\beta$-cell mass and downstream coupling, and determined whether their effects were dependent on GPR55.

We found that both ligands reversibly stimulated insulin secretion from isolated mouse and human islets, in agreement with earlier reports of direct stimulatory effects of AM251 and SR141716A [21, 39] in perifused human islets. Our observations that SR141716A evoked insulin release insulin-positive cells per islet; c mean islet area $\left(\mu \mathrm{m}^{2}\right)$ and $\mathbf{d}$ number of $\beta$-cells (insulin-positive cells) per islet. Data were obtained from multiple acquisitions of 47-95 islets per condition, each with a minimum of eight paraffin sections for analysis. $N=6$ mice per genotype, three independent experiments. $* * * P<0.001$ and $* * * * P<0.0001$ vs. vehicle $G p r 55^{+/+}$or $G p r 55^{-/-}$. Data were analysed using Wilcoxon signed rank test (b) or one-way ANOVA, followed by Dunnett's multiple comparison post test $(\mathbf{c}, \mathbf{d})$

at $2 \mathrm{mM}$ glucose are in agreement with the requirement for some rimonabant-treated patients to reduce their antidiabetic medication [15], and induction of hypoglycaemic episodes by rimonabant in some insulin-treated patients with type 2 diabetes [44]. AM251 also increased insulin secretion from human islets at $2 \mathrm{mM}$ glucose, but was without effect in mouse islets at this sub-stimulatory glucose concentration. These differences in the glucose-dependent effects of AM251 between human and mouse islets may be a consequence of the left-shifted glucose concentration-response profile in human islets [45] or it may reflect species-dependent differences in islet morphology [46] and cannabinoid receptor distribution [2] or arrangement of distinct cannabinoid receptor isoforms within islets [39]. The maintenance of the insulinotropic effects of SR141716A and AM251 in islets isolated from $\mathrm{Gpr} 55^{-/-}$mice demonstrated that their capacity to stimulate insulin secretion is not dependent on GPR55 activation. 


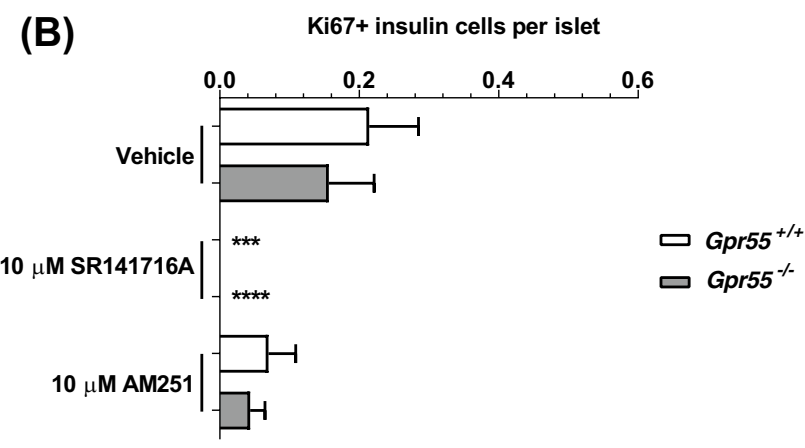

(C)

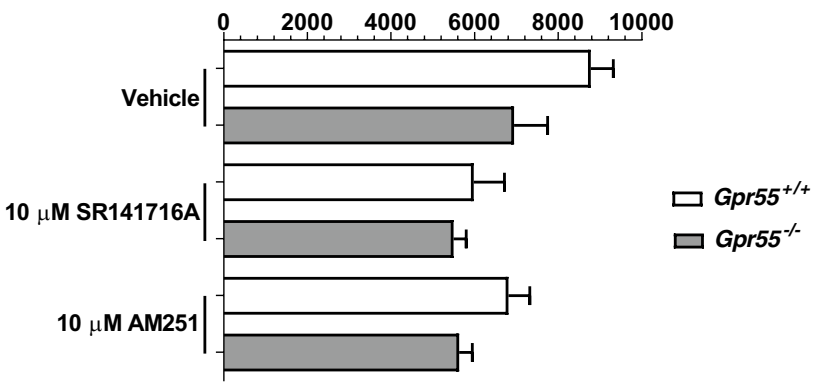

(D)

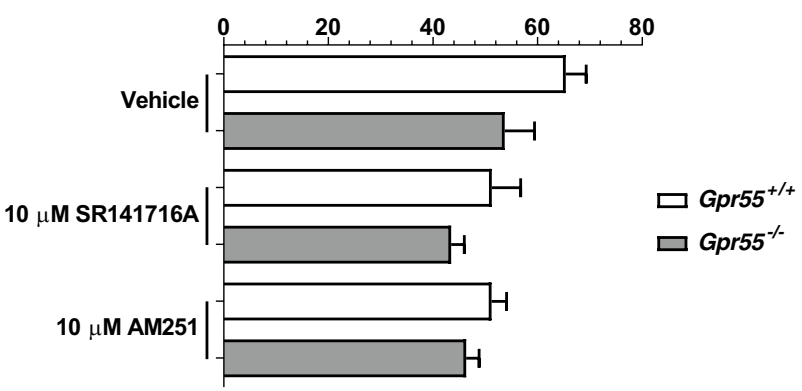

Fig. 7 (continued)

The promiscuity in receptor signalling of cannabinoid ligands extends beyond $\mathrm{CB}_{1} / \mathrm{GPR} 55$, and additional GPCRs that are targeted by cannabinoids have been identified, although progress in classification and validation is dependent on identification of the endogenous ligands and development of selective receptor ligands [47]. As SR141716A- and AM251-stimulated insulin secretion was GPR55-independent we investigated the expression of putative islet cannabinoid receptors through which they could act, and determined whether there were alterations in expression in islets in which GPR55 had been deleted. We focused on mRNAs encoding GPR119, GPR92 (Lpar5), GPR18, $\mathrm{CB}_{1}$, OPRD1 and TRPV1 since they have previously been implicated as targets of cannabinoids [48-51]. In addition, we quantified Gpr3, Gpr6 and Gpr 12 mRNAs because these orphan $\mathrm{G}_{\mathrm{s}}$-coupled Class A GPCRs have a close phylogenetic relationship with cannabinoid receptors and the phytocannabinoid cannabidiol has recently been identified to act as an inverse agonist at these receptors [52]. We found that in addition to $\mathrm{CB}_{1}(\mathrm{Cnrl})$ mouse islets also expressed mRNAs encoding $\mathrm{G}_{\mathrm{s}}$-coupled GPR119 and GPR6, $\mathrm{G}_{\mathrm{q}}$-coupled GPR18 and GPR92 (Lpar5), and the non-selective cation channel TRPV1 while mRNAencoding $\mathrm{G}_{\mathrm{i}}$-coupled delta-opioid receptor $(O p d r l)$ was absent, and Gpr3 and Gpr 12 mRNAs were only expressed at trace levels. Cnrl, Lpar5 and Trpv1 were upregulated following GPR55 deletion, while mRNA encoding GPR 119 was significantly decreased in $\mathrm{Gpr} 55^{-/-}$islets. To add to the complexity, GPR55 may be able to form heterodimers with $\mathrm{CB}_{1}$ receptors and impairment of this following deletion of GPR55 and the consequent upregulation of Cnrl in islets could have functional implications for SR141716A and AM251 signalling. However, our previous observations that $\mathrm{CB}_{1}$ agonists stimulate insulin secretion $[21,22]$ are inconsistent with the GPR55-independent effects of SR141716A and AM251 on insulin release being via upregulation of $\mathrm{CB}_{1}$ receptors in islets from $\mathrm{Gpr} 55^{-/-}$mice, since these ligands are $\mathrm{CB}_{1}$ antagonists.

Quantification of islet cAMP levels indicated that neither ligand affected basal or forskolin-stimulated cAMP production in either $\mathrm{Gpr} 55^{+/+}$or $\mathrm{Gpr} 55^{-/-}$islets, or human islets, suggesting that it was unlikely that they were having inverse agonist effects at $\mathrm{CB}_{1}$ receptors or signaling via $\mathrm{G}_{\mathrm{s}}$-coupled receptors such as GPR119 or GPR6. However, given that there is evidence of biased agonist activity by cannabinoids [53] and we have shown that both ligands significantly elevated $\mathrm{IP}_{1}$ production in isolated mouse and human islets we cannot rule out SR141716A and/or AM251 signalling through a nominally $\mathrm{G}_{\mathrm{s}}$-coupled receptor via $\mathrm{G}_{\mathrm{q}}$-biased signalling. The elevation in $\mathrm{IP}_{1}$ implies GPR55-independent, $\mathrm{G}_{\mathrm{q}-\mathrm{c}}$ coupled receptor signalling by SR141716A and AM251 in islets and further studies using inhibitors of $G_{q}$ and PLC are required to confirm this mechanism of action in islets. Possible $\mathrm{G}_{\mathrm{q}}$-coupled candidates are GPR18 or GPR92, both of which are phylogenetically closely related to GPR55 [50] and activated by some cannabinoids [50, 51]. It has been reported that GPR18 and GPR92 activation is associated with transient elevation of $\left[\mathrm{Ca}^{2+}\right]_{i}[50,54]$, consistent with our $\mathrm{IP}_{1}$ data, although nothing is known about the functional role of these receptors in islets. We did not detect GPR18 mRNA in human islets [55], so this receptor cannot be responsible for our observations of increased $\mathrm{IP}_{1}$ generation in human islets in response to SR141716A and AM251. GPR92 is a plausible candidate mediating the effects of SR141716A and AM251 in islets, and its upregulation following GPR55 deletion could be responsible for the elevated insulin secretory response to SR141716A that was observed in $\mathrm{Gpr} 55^{-/-}$islets. Further study in this area is dependent on 

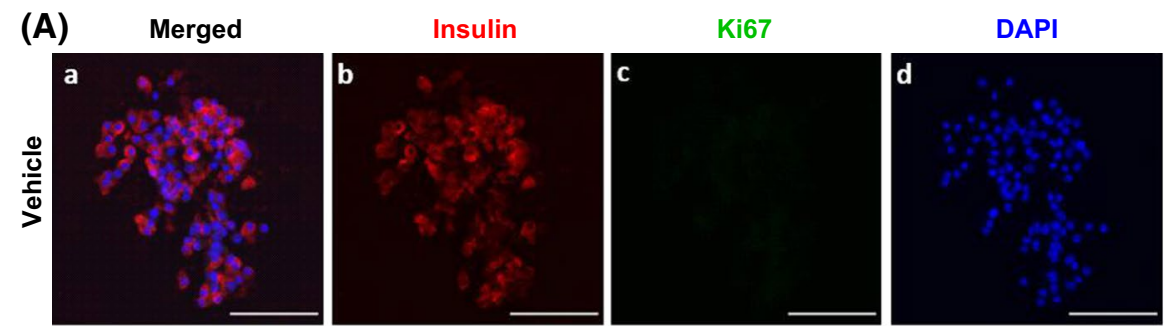

Insulin+ Ki67
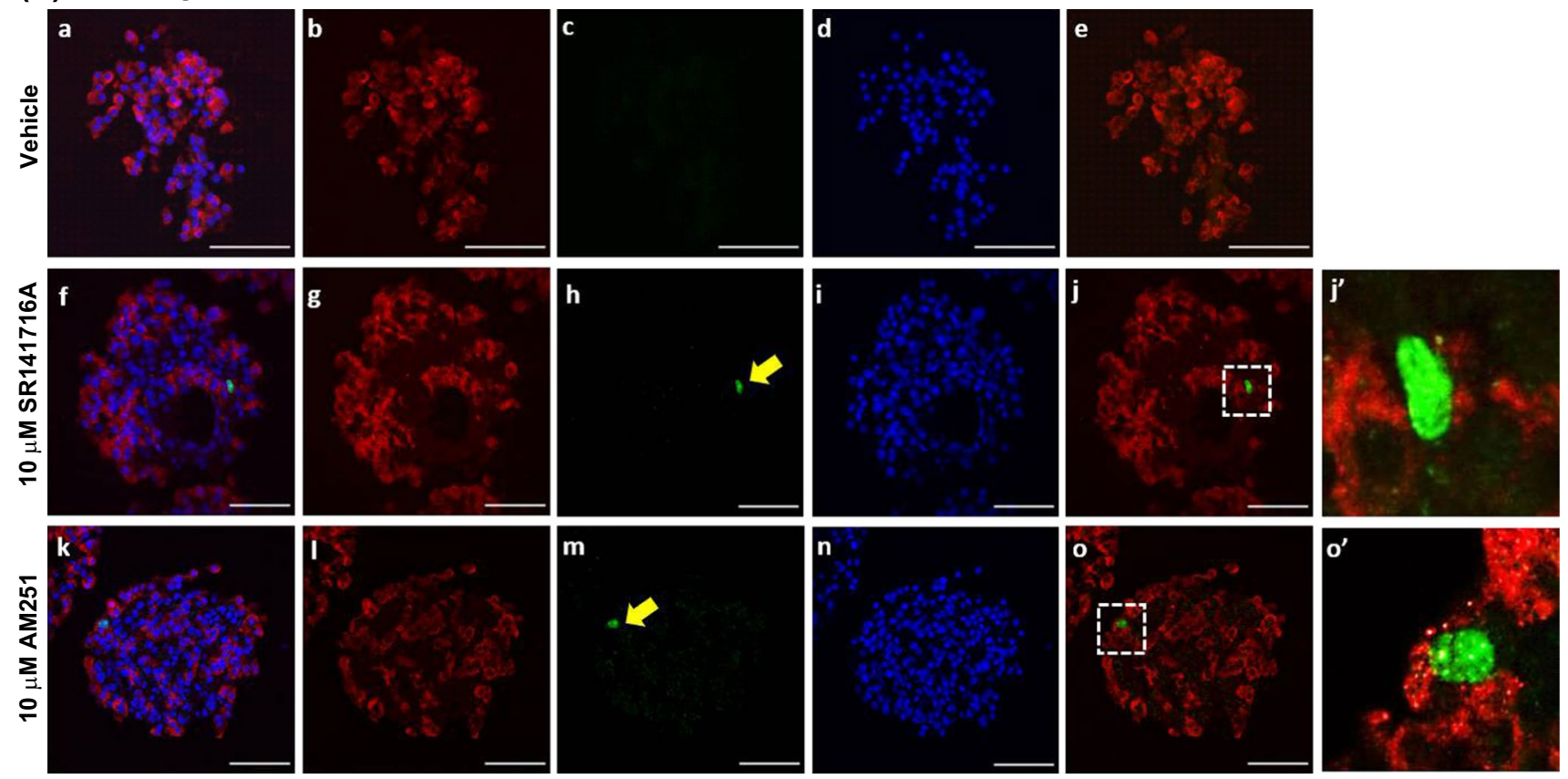

Fig. 8 Effects of SR141716A and AM251 on human $\beta$-cell proliferation. Representative confocal images of paraffin-embedded sections of human islets probed with antibodies directed against insulin (red) and Ki67 (green), and DAPI staining (nuclei; blue) after maintenance of 250 islets in culture for $48 \mathrm{~h}$ in the absence or presence of $10 \mu \mathrm{M}$ SR141716A or AM251 (a). Scale bar $=50 \mu \mathrm{m}$. Post-acquisition analyses were performed with Fiji Image $\mathbf{J}$ software and are shown in $\mathbf{b}-$

the availability of GPR92-selective antagonists and studies in islets isolated from $\mathrm{Lpar}^{-/-}$mice.

Our qPCR analysis also indicated that Trpv1 mRNA was upregulated $15.3 \pm 4.3$-fold in islets from $\mathrm{Gpr} 55^{-/-}$mice and it is possible that TRPV1 activation by SR141716A and AM251 was responsible, at least in part, for the stimulatory effects that we observed in islets following GPR55 deletion. Activation of this cation channel by capsaicin is coupled to TRPV1-dependent stimulation of calcium in INS-1E $\beta$-cells [56] and insulin secretion in mice [57, 58]. However, while capsaicin also stimulates insulin secretion in minced pancreas samples [57] and RIN insulinoma cells [58] it was without effect on non-selective cationic currents in primary rat $\beta$-cells [59] and failed to increase calcium in primary rat and human $\beta$-cells [56]. There is no information to date on the effects of SR141716A and AM251 via TRPV1 in islets, but as $\operatorname{Trpv1^{-/}}$ mice are available for research future studies should be directed to determine whether stimulation by these ligands is reduced or abolished in islets isolated from these mice.

We have previously reported that LH-21 protected mouse and human islets from apoptosis in vitro through a GPR55dependent mechanism [4] and had anti-inflammatory and cytoprotective effects on islets when administered in vivo d: b number of Ki67- and insulin-positive cells per islet; $\mathbf{c}$ mean islet area $\left(\mu \mathrm{m}^{2}\right)$ and $\mathbf{d}$ number of $\beta$-cells (insulin-positive cells) per islet. Data were obtained from multiple acquisitions of 169-210 islets per condition, each with a minimum of eight paraffin sections for analysis from three human donors. $* * * P<0.001$ and $* * * * P<0.0001$ vs. vehicle. Data were analysed using one-way ANOVA, followed by Dunnett's multiple comparison post test

[60], while exposure to $\mathrm{CB}_{1}$ and $\mathrm{CB}_{2}$ agonists did not affect mouse or human islet apoptosis [61, 62]. Conversely, the endocannabinoid system has been implicated in mediating increased islet apoptosis [63, 64]. In the current study we showed that SR141716A and AM251 have direct antiapoptotic effects in isolated mouse and human islets and the use of islets from $\mathrm{Gpr} 55^{-/-}$mice indicated that, as for stimulation of insulin secretion, and $\mathrm{IP}_{1}$ generation, this was through a GPR55-independent cascade. Upregulation of $\mathrm{CB}_{1}$ receptors in islets from $\mathrm{Gpr} 55^{-/-}$mice could contribute to the anti-apoptotic effects of the cannabinoid ligands in these islets since JD5037, a $\mathrm{CB}_{1}$ receptor inverse agonist, reduced TUNEL-positive cells in islets [65].

Both ligands also stimulated human $\beta$-cell proliferation, but SR141716A abolished and AM251 reduced the low level of mouse $\beta$-cell proliferation. The reasons underlying these differences in effects of SR141716A and AM251 on $\beta$-cell proliferation in human and mouse islets are not known, but it is possible that they were related to the islet sources: islets were isolated from lean, male WT and $\mathrm{Gpr} 55^{-/-}$mice, whereas the human islets were from obese, female donors (BMI of $28.9 \pm 0.96$ ), where $\beta$-cell expansion capacity is enhanced [66]. Our availability of islets from normal weight donors was not sufficient for us 
(B)

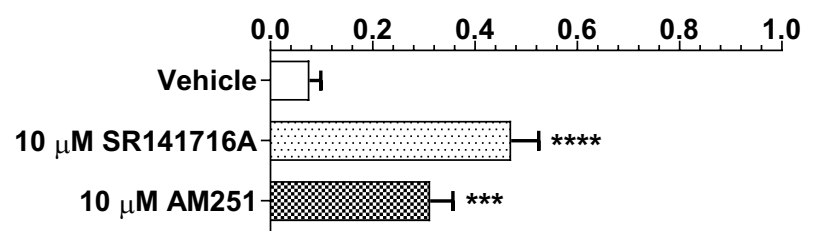

(C)

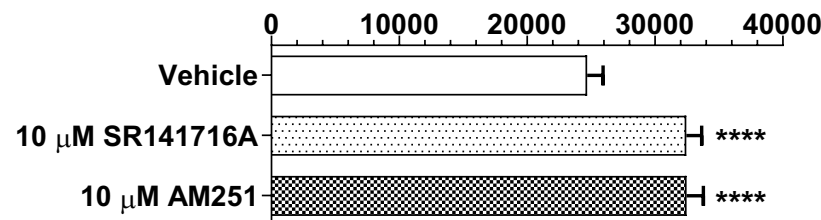

(D)

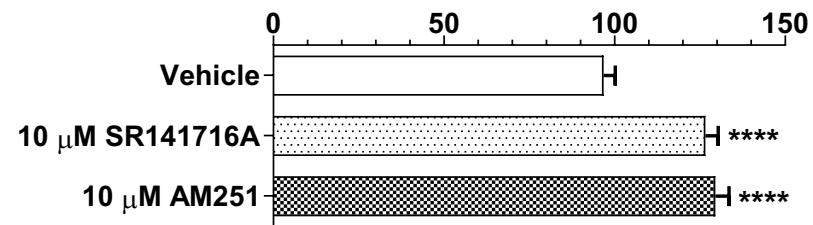

Fig. 8 (continued)

to directly compare $\beta$-cell proliferation in lean populations of mouse and human islets, to determine whether the stimulatory effects of SR141716A and AM251 were indeed secondary to the islets having been obtained from obese donors. Alternatively, the differences may reflect speciesdependent variations since anti-proliferative effects of SR141716A and AM251 have previously been reported in mouse preadipocytes [67] and mouse olfactory epithelium [68], consistent with our observations. We observed enhanced human $\beta$-cell proliferation in islets from three different donors, and it is possible that activation of GPR92 in human islets mediates this stimulatory effect on proliferation, as it does in human keratinocytes [69, 70]. SR141716A and AM251 also significantly increased human islet area and the number of $\beta$-cells per islet: it is unlikely that human islet $\beta$-cell proliferation fully accounts for the increases in these parameters given the very small increase in proliferation in response to SR141716A and AM251 ( $<1 \mathrm{Ki}^{+} 7^{+} \beta$-cell per islet). Therefore, since we observed that the ligands decreased stimulated human islet apoptosis the most likely explanation for increased human islet area and $\beta$-cell number following rimonabant and AM251 treatment is that these ligands protected against $\beta$-cell apoptosis induced by maintenance of 250 islets in culture without medium change for $48 \mathrm{~h}$, consistent with the protective effects of GPR55 agonists and $\mathrm{CB}_{1}$ antagonists against human and mouse islet apoptosis that have been previously reported $[4,65]$.

In summary, our work provides the first evidence that SR141716A and AM251 are not GPR55 agonists in islets, as their effects are maintained in islets from $\mathrm{Fpr}_{5} 5^{-/-}$mice. Our observations of stimulation of insulin secretion and human $\beta$-cell proliferation, and protection against apoptosis in vitro, support SR141716A and AM251 having direct beneficial effects on islet function. However, their ability to induce insulin release from human islets at sub-stimulatory glucose concentrations contra-indicates against their use for treating type 2 diabetes as this could lead to hypoglycaemia in vivo. Additionally, our qPCR data showing that deletion of Gpr55 promotes upregulation of Cnrl, Lpar5 and Trpv1, and downregulation of Gpr119 suggest a potential crossregulation between GPR55 and other cannabinoid receptors in islets that warrants further research.

Acknowledgements We are grateful to Diabetes UK for supporting this research (11/0004397). We thank the families of the pancreas donors for making islets available for this research and Professor David Baker, Blizard Institute, Barts and The London School of Medicine and Dentistry, London, UK, for providing $G p r 55^{-/-}$mice to establish our colony.

Author contributions IRM designed and performed the experiments, analysed and interpreted the data, and wrote the manuscript. BL, PA and AP performed experiments. SJP designed the experiments, analysed and interpreted the data, and wrote the manuscript. All the authors revised the manuscript. SJP and IRM are the guarantors of this work and, as such, take responsibility for the integrity of the data and the accuracy of the data analysis.

\section{Compliance with ethical standards}

Conflict of interest No potential conflicts of interest relevant to this article were reported.

Open Access This article is licensed under a Creative Commons Attribution 4.0 International License, which permits use, sharing, adaptation, distribution and reproduction in any medium or format, as long as you give appropriate credit to the original author(s) and the source, provide a link to the Creative Commons licence, and indicate if changes were made. The images or other third party material in this article are included in the article's Creative Commons licence, unless indicated otherwise in a credit line to the material. If material is not included in the article's Creative Commons licence and your intended use is not permitted by statutory regulation or exceeds the permitted use, you will need to obtain permission directly from the copyright holder. To view a copy of this licence, visit http://creativecommons.org/licenses/by/4.0/.

\section{References}

1. Rorsman P, Ashcroft FM (2018) Pancreatic beta-cell electrical activity and insulin secretion: of mice and men. Physiol Rev 98(1):117-214. https://doi.org/10.1152/physrev.00008.2017 
2. Li C, Jones PM, Persaud SJ (2011) Role of the endocannabinoid system in food intake, energy homeostasis and regulation of the endocrine pancreas. Pharmacol Ther 129(3):307-320. https://doi. org/10.1016/j.pharmthera.2010.10.006

3. Liu B, Song S, Ruz-Maldonado I et al (2017c) GPR55-dependent stimulation of insulin secretion from isolated mouse and human islets of Langerhans. Diabetes Obes Metab 18(12):1263-1273. https://doi.org/10.1111/dom.12780

4. Ruz-Maldonado I, Pingitore A, Liu B et al (2018) LH-21 and abnormal cannabidiol improve beta-cell function in isolated human and mouse islets through GPR55-dependent and -independent signalling. Diabetes Obes Metab 20(4):930-942. https:// doi.org/10.1111/dom.13180

5. Romero-Zerbo SY, Rafacho A, Diaz-Arteaga A et al (2011) A role for the putative cannabinoid receptor GPR55 in the islets of Langerhans. J Endocrinol 211(2):177-185. https://doi. org/10.1530/JOE-11-0166

6. Li C, Bowe JE, Jones PM, Persaud SJ (2010) Expression and function of cannabinoid receptors in mouse islets. Islets 2(5):293-302

7. Di Marzo V, Matias I (2005) Endocannabinoid control of food intake and energy balance. Nat Neurosci 8(5):585-589. https:// doi.org/10.1038/nn1457

8. Witkamp RF (2018) The role of fatty acids and their endocannabinoid-like derivatives in the molecular regulation of appetite. Mol Aspects Med 64:45-67. https://doi.org/10.1016/j. mam.2018.01.002

9. Rinaldi-Carmona M, Barth F, Heaulme M et al (1994) SR141716A, a potent and selective antagonist of the brain cannabinoid receptor. FEBS Lett 350(2-3):240-244

10. Pertwee RG (1997) Pharmacology of cannabinoid CB1 and CB2 receptors. Pharmacol Ther 74(2):129-180

11. Sun Y, Chen J (2012) Rimonabant, gastrointestinal motility and obesity. Curr Neuropharmacol 10(3):212-218. https://doi. org/10.2174/157015912803217297

12. Despres JP, Golay A, Sjostrom L, Rimonabant in Obesity-Lipids Study G (2005) Effects of rimonabant on metabolic risk factors in overweight patients with dyslipidemia. N Engl J Med 353(20):2121-2134. https://doi.org/10.1056/NEJMoa044537

13. Gaal LF, Rissanen AM, Scheen AJ, Ziegler O, Rossner S, Group RI-ES (2005) Effects of the cannabinoid-1 receptor blocker rimonabant on weight reduction and cardiovascular risk factors in overweight patients: 1-year experience from the RIO-Europe study. Lancet 365(9468):1389-1397. https://doi.org/10.1016/ S0140-6736(05)66374-X

14. Pi-Sunyer FX, Aronne LJ, Heshmati HM, Devin J, Rosenstock J, Group RI-NAS (2006) Effect of rimonabant, a cannabinoid-1 receptor blocker, on weight and cardiometabolic risk factors in overweight or obese patients: RIO-North America: a randomized controlled trial. JAMA 295(7):761-775. https://doi.org/10.1001/ jama.295.7.761

15. Scheen AJ, Finer N, Hollander P, Jensen MD, Gaal LF, Group RI-DS (2006) Efficacy and tolerability of rimonabant in overweight or obese patients with type 2 diabetes: a randomised controlled study. Lancet 368(9548):1660-1672. https://doi. org/10.1016/S0140-6736(06)69571-8

16. Scheen AJ, Van Gaal LG, Despres JP, Pi-Sunyer X, Golay A, Hanotin C (2006) Rimonabant improves cardiometabolic risk profile in obese or overweight subjects: overview of RIO studies. Revue Medicale Suisse 2(76):1916-1923

17. Gomez R, Navarro M, Ferrer B et al (2002) A peripheral mechanism for CB1 cannabinoid receptor-dependent modulation of feeding. J Neurosci 22(21):9612-9617

18. Hildebrandt AL, Kelly-Sullivan DM, Black SC (2003) Antiobesity effects of chronic cannabinoid CB1 receptor antagonist treatment in diet-induced obese mice. Eur J Pharmacol 462(1-3):125-132
19. Nissen SE, Nicholls SJ, Wolski K et al (2008) Effect of rimonabant on progression of atherosclerosis in patients with abdominal obesity and coronary artery disease: the STRADIVARIUS randomized controlled trial. JAMA 299(13):1547-1560. https://doi. org/10.1001/jama.299.13.1547

20. Wright SM, Dikkers C, Aronne LJ (2008) Rimonabant: new data and emerging experience. Curr Atheroscler Rep 10(1):71-78

21. Li C, Bowe JE, Huang GC, Amiel SA, Jones PM, Persaud SJ (2011) Cannabinoid receptor agonists and antagonists stimulate insulin secretion from isolated human islets of Langerhans. Diabetes Obes Metab 13(10):903-910. https://doi.org/10.111 1/j.1463-1326.2011.01422.x

22. Li C, Jones PM, Persaud SJ (2010) Cannabinoid receptors are coupled to stimulation of insulin secretion from mouse MIN6 beta-cells. Cell Physiol Biochem 26(2):187-196. https://doi. org/10.1159/000320527

23. Kapur A, Zhao P, Sharir H et al (2009) Atypical responsiveness of the orphan receptor GPR55 to cannabinoid ligands. J Biol Chem 284(43):29817-29827. https://doi.org/10.1074/jbc.M109.050187

24. Henstridge CM, Balenga NA, Schroder R et al (2010) GPR55 ligands promote receptor coupling to multiple signalling pathways. Br J Pharmacol 160(3):604-614. https://doi.org/10.111 1/j.1476-5381.2009.00625.x

25. Yin H, Chu A, Li W et al (2009) Lipid G protein-coupled receptor ligand identification using beta-arrestin PathHunter assay. J Biol Chem 284(18):12328-12338. https://doi.org/10.1074/jbc.M8065 16200

26. Ryberg E, Larsson N, Sjogren S et al (2007) The orphan receptor GPR55 is a novel cannabinoid receptor. Br J Pharmacol 152(7):1092-1101. https://doi.org/10.1038/sj.bjp.0707460

27. Sisay S, Pryce G, Jackson SJ et al (2013) Genetic background can result in a marked or minimal effect of gene knockout (GPR55 and $\mathrm{CB} 2$ receptor) in experimental autoimmune encephalomyelitis models of multiple sclerosis. PLoS ONE 8(10):e76907. https:// doi.org/10.1371/journal.pone.0076907

28. Papadimitriou A, King AJ, Jones PM, Persaud SJ (2007) Antiapoptotic effects of arachidonic acid and prostaglandin E2 in pancreatic beta-cells. Cell Physiol Biochem 20(5):607-616. https:// doi.org/10.1159/000107544

29. Huang GC, Zhao M, Jones P et al (2004) The development of new density gradient media for purifying human islets and isletquality assessments. Transplantation 77(1):143-145. https://doi. org/10.1097/01.TP.0000100401.62912.B2

30. Pingitore A, Chambers ES, Hill T et al (2017) The diet-derived short chain fatty acid propionate improves beta-cell function in humans and stimulates insulin secretion from human islets in vitro. Diabetes Obes Metab 19(2):257-265. https://doi. org/10.1111/dom.12811

31. Gey GO, Gey MK (1936) The maintenance of human normal cells and tumor cells in continuous culture: I. Preliminary report: cultivation of mesoblastic tumors and normal tissue and notes on methods of cultivation. Am J Cancer 27:45-76

32. Jones PM, Salmon DM, Howell SL (1988) Protein phosphorylation in electrically permeabilized islets of Langerhans. Effects of $\mathrm{Ca}^{2+}$, cyclic AMP, a phorbol ester and noradrenaline. Biochem $\mathrm{J}$ 254(2):397-403

33. Heynen-Genel S, Dahl R, Shi S, Milan L, Hariharan S, Sergienko E, Hedrick M, Dad S, Stonich D, Su Y, Vicchiarelli M, Mangravita-Novo A, Smith LH, Chung TDY, Sharir H, Caron MG, Barak LS, Abood ME (2010) Screening for selective ligands for GPR55 - antagonists. In: Probe reports from the nih molecular libraries program. [Internet]. National Center for Biotechnology Information (US), Bethesda (MD)

34. Fong TM (2010) Measurement of inverse agonism of the cannabinoid receptors. Methods Enzymol 485:139-145. https://doi. org/10.1016/B978-0-12-381296-4.00008-7 
35. Gilon P, Henquin JC (2001) Mechanisms and physiological significance of the cholinergic control of pancreatic beta-cell function. Endocr Rev 22(5):565-604. https://doi.org/10.1210/ edrv.22.5.0440

36. Getty-Kaushik L, Richard AM, Deeney JT, Krawczyk S, Shirihai O, Corkey BE (2009) The CB1 antagonist rimonabant decreases insulin hypersecretion in rat pancreatic islets. Obesity 17(10):1856-1860. https://doi.org/10.1038/oby.2009.234

37. Bermudez-Silva FJ, Romero-Zerbo SY, Haissaguerre M et al (2016) The cannabinoid CB1 receptor and mTORC1 signalling pathways interact to modulate glucose homeostasis in mice. Dis Models Mech 9(1):51-61. https://doi.org/10.1242/dmm.020750

38. Ulgen F, Kuhn MC, Cupisti K et al (2011) The CB-1 receptor antagonist rimonabant modulates the interaction between adipocytes and pancreatic beta-cells in vitro. Exp Clin Endocrinol Diabetes 119(1):41-46. https://doi.org/10.1055/s-0030-1261963

39. Gonzalez-Mariscal I, Krzysik-Walker SM, Doyle ME et al (2016) Human CB1 receptor isoforms, present in hepatocytes and betacells, are involved in regulating metabolism. Sci Rep 6:33302. https ://doi.org/10.1038/srep33302

40. Duvivier VF, Delafoy-Plasse L, Delion V et al (2009) Beneficial effect of a chronic treatment with rimonabant on pancreatic function and beta-cell morphology in Zucker Fatty rats. Eur J Pharmacol 616(1-3):314-320. https://doi.org/10.1016/j.ejphar.2009.05.024

41. McKillop AM, Moran BM, Abdel-Wahab YH, Flatt PR (2013) Evaluation of the insulin releasing and antihyperglycaemic activities of GPR55 lipid agonists using clonal beta-cells, isolated pancreatic islets and mice. Br J Pharmacol 170(5):978-990. https://doi. org/10.1111/bph.12356

42. Gonzalez-Mariscal I, Krzysik-Walker SM, Kim W, Rouse M, Egan JM (2016) Blockade of cannabinoid 1 receptor improves GLP-1R mediated insulin secretion in mice. Mol Cell Endocrinol 423:1-10. https://doi.org/10.1016/j.mce.2015.12.015

43. Tam J, Vemuri VK, Liu J et al (2010) Peripheral CB1 cannabinoid receptor blockade improves cardiometabolic risk in mouse models of obesity. J Clin Invest 120(8):2953-2966. https://doi.org/10.1172/ JCI42551

44. Hollander PA, Amod A, Litwak LE, Chaudhari U, Group AS (2010) Effect of rimonabant on glycemic control in insulin-treated type 2 diabetes: the ARPEGGIO trial. Diabetes Care 33(3):605-607. https ://doi.org/10.2337/dc09-0455

45. Pingitore A, Ruz-Maldonado I, Liu B, Huang GC, Choudhary P, Persaud SJ (2017) Dynamic profiling of insulin secretion and ATP generation in isolated human and mouse islets reveals differential glucose sensitivity. Cell Physiol Biochem 44(4):1352-1359. https ://doi.org/10.1159/000485532

46. Cabrera O, Berman DM, Kenyon NS, Ricordi C, Berggren PO, Caicedo A (2006) The unique cytoarchitecture of human pancreatic islets has implications for islet cell function. Proc Natl Acad Sci USA 103(7):2334-2339. https://doi.org/10.1073/pnas.0510790103

47. Morales P, Reggio PH (2017) An update on non-CB1, non-CB2 cannabinoid related G-protein-coupled receptors. Cannabis Cannabinoid Res 2(1):265-273. https://doi.org/10.1089/can.2017.0036

48. Ye L, Cao Z, Wang W, Zhou N (2019) New insights in cannabinoid receptor structure and signaling. Curr Mol Pharmacol 12(3):239 248. https://doi.org/10.2174/1874467212666190215112036

49. Zador F, Kocsis D, Borsodi A, Benyhe S (2014) Micromolar concentrations of rimonabant directly inhibits delta opioid receptor specific ligand binding and agonist-induced G-protein activity. Neurochem Int 67:14-22. https://doi.org/10.1016/j.neuint.2013.12.005

50. Pertwee RG, Howlett AC, Abood ME et al (2010) International Union of Basic and Clinical Pharmacology. LXXIX. Cannabinoid receptors and their ligands: beyond $\mathrm{CB} 1$ and $\mathrm{CB} 2$. Pharmacol Rev 62(4):588-631. https://doi.org/10.1124/pr.110.003004

51. Console-Bram L, Brailoiu E, Brailoiu GC, Sharir H, Abood ME (2014) Activation of GPR18 by cannabinoid compounds: a tale of biased agonism. Br J Pharmacol 171(16):3908-3917. https://doi. org/10.1111/bph.12746

52. Laun AS, Shrader SH, Brown KJ, Song ZH (2019) GPR3, GPR6, and GPR12 as novel molecular targets: their biological functions and interaction with cannabidiol. Acta Pharmacol Sin 40(3):300-308. https://doi.org/10.1038/s41401-018-0031-9

53. Priestley R, Glass M, Kendall D (2017) Functional selectivity at cannabinoid receptors. Adv Pharmacol 80:207-221. https://doi. org/10.1016/bs.apha.2017.03.005

54. Kohno M, Hasegawa H, Inoue A et al (2006) Identification of $\mathrm{N}$-arachidonylglycine as the endogenous ligand for orphan G-protein-coupled receptor GPR18. Biochem Biophys Res Commun 347(3):827-832. https://doi.org/10.1016/j.bbrc.2006.06.175

55. Amisten S, Neville M, Hawkes R, Persaud SJ, Karpe F, Salehi A (2015) An atlas of G-protein coupled receptor expression and function in human subcutaneous adipose tissue. Pharmacol Ther 146:61-93. https://doi.org/10.1016/j.pharmthera.2014.09.007

56. Fagelskiold AJ, Kannisto K, Bostrom A et al (2012) Insulinsecreting INS-1E cells express functional TRPV1 channels. Islets 4(1):56-63. https://doi.org/10.4161/isl.18915

57. Zhong B, Ma S, Wang DH (2019) TRPV1 mediates glucoseinduced insulin secretion through releasing neuropeptides. In Vivo 33(5):1431-1437. https://doi.org/10.21873/invivo.11621

58. Akiba Y, Kato S, Katsube K et al (2004) Transient receptor potential vanilloid subfamily 1 expressed in pancreatic islet beta cells modulates insulin secretion in rats. Biochem Biophys Res Commun 321(1):219-225. https://doi.org/10.1016/j.bbrc.2004.06.149

59. Diaz-Garcia CM, Morales-Lazaro SL, Sanchez-Soto C, Velasco M, Rosenbaum T, Hiriart M (2014) Role for the TRPV1 channel in insulin secretion from pancreatic beta cells. J Membr Biol 247(6):479-491. https://doi.org/10.1007/s00232-014-9658-8

60. Romero-Zerbo SY, Ruz-Maldonado I, Espinosa-Jimenez V et al (2017) The cannabinoid ligand LH-21 reduces anxiety and improves glucose handling in diet-induced obese pre-diabetic mice. Sci Rep 7(1):3946. https://doi.org/10.1038/s41598-017-03292-w

61. Vilches-Flores A, Hauge-Evans AC, Jones PM, Persaud SJ (2013) Chronic activation of cannabinoid receptors in vitro does not compromise mouse islet function. Clin Sci 124(7):467-478. https://doi. org/10.1042/CS20120447

62. Vilches-Flores A, Franklin Z, Hauge-Evans AC et al (2016) Prolonged activation of human islet cannabinoid receptors in vitro induces adaptation but not dysfunction. BBA Clin 5:143-150. https ://doi.org/10.1016/j.bbacli.2016.03.009

63. Kim W, Doyle ME, Liu Z et al (2011) Cannabinoids inhibit insulin receptor signaling in pancreatic beta-cells. Diabetes 60(4):11981209. https://doi.org/10.2337/db10-1550

64. Kim W, Lao Q, Shin YK et al (2012) Cannabinoids induce pancreatic beta-cell death by directly inhibiting insulin receptor activation. Sci Signal 5(216):ra23. https://doi.org/10.1126/scisignal.2002519

65. Jourdan T, Godlewski G, Cinar R et al (2013) Activation of the Nlrp3 inflammasome in infiltrating macrophages by endocannabinoids mediates beta cell loss in type 2 diabetes. Nat Med 19(9):1132-1140. https://doi.org/10.1038/nm.3265

66. Linnemann AK, Baan M, Davis DB (2014) Pancreatic betacell proliferation in obesity. Adv Nutr 5(3):278-288. https://doi. org/10.3945/an.113.005488

67. Gary-Bobo M, Elachouri G, Scatton B, Le Fur G, Oury-Donat F, Bensaid M (2006) The cannabinoid CB1 receptor antagonist rimonabant (SR141716) inhibits cell proliferation and increases markers of adipocyte maturation in cultured mouse $3 \mathrm{~T} 3 \mathrm{~F} 442 \mathrm{~A}$ preadipocytes. Mol Pharmacol 69(2):471-478. https://doi.org/10.1124/ mol.105.015040

68. Hutch CR, Hegg CC (2016) Cannabinoid receptor signaling induces proliferation but not neurogenesis in the mouse olfactory epithelium. Neurogenesis (Austin) 3(1):e1118177. https://doi. org/10.1080/23262133.2015.1118177 
69. Piazza GA, Ritter JL, Baracka CA (1995) Lysophosphatidic acid induction of transforming growth factors alpha and beta: modulation of proliferation and differentiation in cultured human keratinocytes and mouse skin. Exp Cell Res 216(1):51-64. https://doi. org/10.1006/excr.1995.1007

70. Sumitomo A, Siriwach R, Thumkeo D et al (2018) LPA induces keratinocyte differentiation and promotes skin barrier function through the LPAR1/LPAR5-RHO-ROCK-SRF axis. J Invest Dermatol. https://doi.org/10.1016/j.jid.2018.10.034

Publisher's Note Springer Nature remains neutral with regard to jurisdictional claims in published maps and institutional affiliations. 